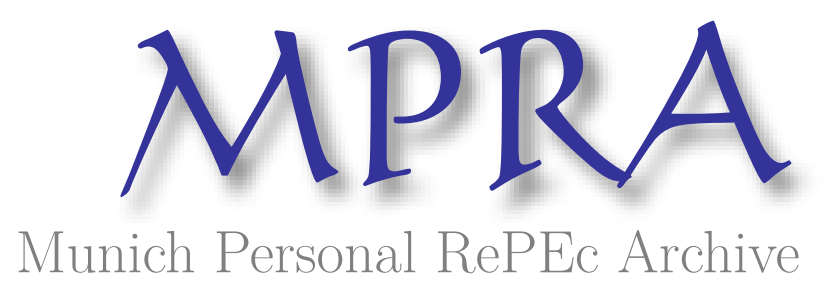

\title{
Associating Turkey with the Transatlantic Trade and Investment Partnership: A costly (re-) engagement?
}

\author{
Altay, Serdar \\ Istanbul Technical University, Faculty of Management, Department \\ of Economics
}

2018

Online at https://mpra.ub.uni-muenchen.de/87454/

MPRA Paper No. 87454, posted 21 Jun 2018 11:36 UTC 


\title{
Associating Turkey with the Transatlantic Trade and Investment Partnership: A costly (re-) engagement?
}

\author{
Serdar Altay
}

Economics, Istanbul Teknik Universitesi, Istanbul, Turkey

\section{\begin{tabular}{l|l}
1 & INTRODUCTION
\end{tabular}}

Turkey has closely monitored the Transatlantic Trade and Investment Partnership (TTIP) negotiations between the United States and the European Union (EU). Ankara is concerned particularly because it has a Customs Union with the European Union (EU) effective since 1996. Specifically, the Customs Union, which was supposed to be an interim step towards Turkey's full EU membership, obliged Ankara to negotiate flanking Free Trade Agreements (FTAs) with third parties that the Europeans have concluded an FTA. However, the Customs Union set no viable mechanisms to incorporate Turkey into EU-level commercial policymaking, either for the selection of potential new FTA partners or to impel those partners to engage in a follow-up deal with Ankara. Over the past two decades, the Turkish governments have pursued concluding EU-mandated FTAs with third parties. Flanking agreements often came with some delay since these parties have not been legally obliged and may not be economically enthusiastic to negotiate a trade deal with Turkey. ${ }^{1}$ In this regard, each new FTA signed by the EU meant a temporary increase in imports of Turkey from a third party which gained de facto duty-free access to the Turkish market via the Customs Union. Each new EU FTA also eroded preferential access of Turkish exporters into the EU markets while it allowed European competitors to enjoy first-entry advantage in third markets. The challenge has become insurmountable since 2006 as the EU reinstated its FTA agenda in a more proactive manner by approaching advanced and sizable economies such as South Korea and Canada. Furthermore, Turkey's EU membership talks that started in 2005 have not been as productive as Ankara had expected, registering little progress mainly due to political drawbacks on both sides and thus leaving the Customs Union as the sole but imperfect instrument commercially linking the two parties.

'For instance, Algeria and South Africa continue to avoid initiating talks for a flanking deal with Turkey, while Mexico has eventually started negotiations after dragging its feet for more than a decade. Despite the lag between the EU's deals and Turkey's, Ankara has succeeded in signing a flanking FTA with most third parties that the EU engaged with. Of 23 FTAs that Turkey has signed, 18 are currently in force and others are in the ratification stage. Negotiations are underway with 12 other parties (Atalay, 2011, p. 3). See Turkish Ministry of Economy and European Commission's websites for details: http://www.economy.gov.tr/ and http://ec.europa.eu/trade/policy/countries-and-regions/agreements/ (accessed 10 August 2016). 
Against this backdrop, the TTIP negotiations have triggered strong reactions in Turkey in a manner reflecting Ankara's ongoing frustration with the Customs Union as well as with long-lasting, but ineffectual EU accession bid. Observers have argued that a transatlantic trade deal without Ankara would shrink Turkish exporters' markets in Europe to the US's favour and inevitably deflect trade from the United States into Turkey (e.g., Cetingulec, 2014; Kirisci, 2013, pp. 13-16; Yesilyurt \& Paul, 2013). The impact studies by analysts of Germany's Ifo Institute fuelled the debate as they suggested that Turkey's economic losses would reach $2.5 \%$ of the Turkish GDP (Felbermayr, Heid, \& Lehwald, 2013, pp. 28-30, 41; Felbermayr, Larch, Flach, Yalcin, \& Benz, 2013, pp. 6-7). Experts have argued for the necessity of Ankara's participation in the TTIP process to prevent any economic downsides as well as to improve turbulent political relations with Atlantic allies (e.g., Aran, 2015, pp. 3-5; Kaleagasi \& Ornarli, 2013; Kirisci, 2013, pp. 17-18). Lobbying Washington, DC and EU capitals, Turkish cabinet members sporadically threatened that Ankara would unilaterally suspend the Customs Union or consider switching it to a more flexible FTA if Turkey was not granted a seat at the TTIP negotiation table (Hurriyet Daily News, 28 March 2013, 28 October 2013; Cetingulec, 2014).

Neither Washington nor Brussels has acquiesced to the Turkish bid of association with the TTIP process, at least during bilateral negotiations, which have already proven sophisticated enough with several technical and politically sensitive issues. The policy debate has continued elaborating upon how to re-engage Turkey with emerging transatlantic commercial architecture following the striking of a potential TTIP deal. Turkish officials suggested the injection of specific provisions into the final TTIP draft for "docking" Turkey, which would apply the pact's obligations "automatically" to the EU's Customs Union partners (Hurriyet Daily News, 16 May 2014, 5 November 2014). Some experts have proposed the launch of "TTIP plus 3" talks after reaching a transatlantic agreement so as to extend the pact to Turkey as well as Mexico and Canada (Akman, 2013, pp. 14-15; Kirisci, 2015). Meanwhile the United States and European governments have opened new consultation channels to turn Ankara's enthusiasm into a more realistic and fruitful reform agenda. As a prerequisite to Turkey's association with TTIP, the Americans called upon Ankara to take steps to address specific problems pertinent to the Turkish intellectual property rights (IPRs) regime, commercial offsets, licensing and certification processes, and transparency and discrimination problems in the government procurement system (D€unya, 8 September 2014; Today's Zaman, 2 October 2014). Similarly, Brussels put forth the "modernisation" of the Customs Union as a necessary step to address the aforementioned "asymmetries" created by its design and to expand its purview from industrial products to also include farming, services and government procurement. Turkish-European consultations have led to a mutual understanding in May 2015 to initiate formal modernisation talks in 2017 (Hurriyet Daily News, 12 May 2015; D€unya, 25 October 2016). In addition, both Europeans and Americans continued to encourage Ankara to accede to the WTO's Government Procurement Agreement (GPA) and effectively participate in the ongoing Trade in Services Agreement (TiSA) talks in Geneva. ${ }^{1}$

The policy debate on TTIP and Turkey has so far intensively focused on the question of "how," rather than "why" Ankara should/would join a potential transatlantic commercial pact. Existing

${ }^{1}$ As a plurilateral initiative to liberalise barriers to global trade in services, the TiSA negotiations started in Geneva in 2012 between 23 parties that constitute the group of "Really Goods Friends of Services" comprising among others the United States, EU and Turkey. 
accounts do not provide a satisfactory rationale that would economically justify a "TTIP plus Turkey" scenario vis-a-vis alternative policy trajectories. Specifically, studies claim Turkey's association with a transatlantic FTA as something beneficial, yet mostly without substantiating this argument with a comprehensive quantitative or qualitative assessment. Although there are a few impact studies using quantitative modelling approaches, these reports generally do not account for multiple critical implications of the "deep integration" agenda that underlie TTIP and other contemporary preferential trade agreements (PTAs). ${ }^{2}$ Utilising insights from the emerging literature on deep integration agreements, this paper intends to provide an encompassing understanding of potential implications for Turkey of specific issues on the transatlantic agenda with their associated compliance and adjustment costs, and policy repercussions. By mapping out the agenda items in market access, regulatory matters and rules, which will require Turkish action, the paper lays out potential benefits and trade-offs that the Turkish economy and policies are likely to encounter in a "TTIP plus Turkey" scenario in comparison with the status quo, that is, a "baseline scenario" (of not associating Turkey with a TTIP). Such an approach also provides clues about the implications of more imminent and likely but less comprehensive re-engagement mechanisms regardless of a factual materialisation of a "TTIP plus Turkey," including a modernised customs union agreement, conclusion of TiSA and Turkey's accession into the GPA.

The remainder of the paper will map out issues on the TTIP agenda that are critical to Turkish industries and the government following a short summary of existing knowledge of the impact of deep integration PTAs. It will then explore the implications of different scenarios for Turkey by evaluating statistical data and findings of quantitative modelling endeavours, and qualitatively comparing relevant Turkish standards and emerging joint transatlantic norms.

\section{ANALYSING THE IMPACT OF DEEP INTEGRATION PTAs}

Standard economic theories envisage PTAs as instruments utilised to neutralise effects of beggar-thyneighbour policies placed by governments to protect uncompetitive industries at a cost of distorting international trade (Baldwin, 2009, 2011). Dismantling of trade barriers such as tariffs following the PTA will spur particular static (one-off) and/or dynamic (longer term) welfare effects thanks to improved terms of trade and more efficient allocation of resources. Static effects include trade creation and trade diversion. Trade creation occurs between PTA parties because of the displacement of less efficient production in favour of more efficient partner country production. Trade diversion takes place as trade between each participant and excluded countries deviate into PTA partners following the deal by displacing more efficient non-partner imports with less efficient production in PTA partner(s). The magnitude of these two opposing effects will determine the aggregate static impacts which vary from one deal to another. PTAs also lead to certain dynamic or growth effects that emerge in the longer term entailing more substantive and pervasive implications critical for developing countries such as a reallocation of economic resources, industrial restructuring and changes to economic efficiency. Overall, PTAs pave the way for some domestic winners but also losers as they incur adjustment costs

\footnotetext{
${ }^{2}$ Following the terminology adopted by the WTO Secretariat, the generic term "PTA" in the paper refers to all reciprocal preferential agreements at regional, bilateral and plurilateral levels that cover free trade agreements and customs unions (WTO, 2012, p. 44).
} 
to uncompetitive firms and industries mostly in the form of diminishing production, exits of firms from the market and rising unemployment (see Porto \& Hoekman, 2010).

The economic impact of PTAs is usually analysed through studying trade and price linkages between markets by taking account of several factual or calibrated parameters. Computable general equilibrium (CGE) models are the most frequently applied tool for an "ex-ante" assessment of a forthcoming agreement (Plummer, Cheong, \& Hamanaka, 2010, pp. 20-24). CGE models quantify economic implications of a deal by comparing the national welfare in the status quo market equilibrium with the post-PTA economic equilibrium calculated for a projected year. For instance, according to the Ifo analysts' study mentioned above, a comprehensive TTIP that covers reduction of both tariffs and non-tariff barriers (NTBs) would in the long run lead to a GDP growth of $13.38 \%$ and $4.68 \%$ for the USA and Germany, respectively (Felbermayr, Larch, et al., 2013, p. 6). ECPR experts generated a more realistic assessment suggesting that an "ambitious" TTIP scenario would boost EU GDP by $0.48 \%$ and US GDP by $0.39 \%$ which amount to EUR 119 billion growth to the EU's national income, and EUR 95 billion expansion to the US GDP by 2027 (Francois, Manchin, Norberg, Pindyuk, \& Tomberger, 2013, pp. 46-47, 50-51).

The large difference between these two forecasts is not only because of methodological differences but also indicative of the difficulty to quantify the effects of PTAs. It also hints the fact that CGE models are imperfect instruments prone to several deficiencies. ${ }^{3}$ Standard quantitative models encounter greater problems that affect the validity of results since the focus of PTAs has recently shifted from border barriers to NTBs and rules by concerning themselves not only with trade of goods but also investment and service flows. Suffice it to note that a particularly challenging task is to quantify the impact of the elimination of NTBs, which are redundant and costly regulations such as divergent standards, conformity measures, and testing and certification requirements installed for purposes of environmental protection, consumer and food safety etc. (Ecorys, 2009). As opposed to "shallow integration" deals, which exclusively address conventional border barriers "deep integration," PTAs increasingly contain "WTO-plus" rules for eliminating NTBs and setting standards in areas such as competition policy, investment protection, labour and environmental conditions etc. (Horn, Mavroidis, \& Sapir, 2010; WTO, 2012, pp. 128-131). In this regard, it becomes particularly problematic to capture the interaction between the regulatory agenda set by new PTAs and preference creation versus trade diversion dynamics outlined above. Since there is no thumb rule to detect and compare the sophistication of the local regulatory environment with PTA commitments, it is particularly hard to measure the "depth" of a PTA, hence its market-opening and standards-converging effects (Kim, 2015, p. 372). In fact, depending on the design of a PTA, the development level and regulatory structure of the parties and outsiders, the regulatory agenda may have both positive and negative implications.

On the upside, some PTA rules, which may be distinguished as "pro-competitive" following in the dichotomy of Patrick Messerlin (2008, p. 5), may engender positive spillovers for the PTA participants and outsiders. For example, the rules that remove domestic or cross-border anticompetitive practices, facilitate trade and improve competition policy are capable of curtailing transaction costs and enhancing domestic competition. Furthermore, the convergence of regulatory systems is likely to

\footnotetext{
${ }^{3}$ CGE models are criticised for their inability to fully account for the time dimension and dynamic effects of PTAs, oversensitivety to the presence and utilisation of economic data, and simplistic theoretical assumptions they are built upon, which may hardly hold in real world (Plummer et al., 2010, p. 23).
} 
improve trade conditions between exporters of parties and nonparties, and among third parties that have adopted standards set by a pact (Chauffour \& Maur, 2011b, pp. 26-27; Francois et al., 2013, pp. 28-29; Hoekman \& Mavroidis, 2015, pp. 8-10). Specifically, enterprises, which previously had to comply with different norms in trading with PTA parties, do face lower transaction costs following the deal. In addition to such direct impact, a PTA may also induce certain indirect spillovers that derive from the adoption of new collective standards by non-parties. Nonetheless, as World Trade Institute scholars proclaim "estimated spill-overs [...] are [...] even more [speculative] than standard trade policy modelling" (Cottier et al., 2014, p. 7). Although it is

TABLE 1 Composition of the changes in GDP after TTIP (in percent, 2027 benchmark with 20\% direct spillovers)

\section{Stemming from the liberalisation of}

$$
\begin{aligned}
& \text { Total b. Total c. Total } \\
& (\mathrm{a}+\mathrm{b}+\quad \text { NTBs NTBs d. Direct e. Indirect } \mathrm{c}+\mathrm{d}+\mathrm{e}) \mathrm{a} \text {. } \\
& \text { Tariffs (goods) (services) spillovers spillovers }
\end{aligned}
$$

Less ambitious ${ }^{\text {a }}$ TTIP

\begin{tabular}{llllllll} 
European Union & 0.27 & 0.1 & 0.12 & 0.01 & 0.03 & 0.01 & 0.02 \\
\hline United States & 0.21 & 0.04 & 0.11 & 0.03 & 0.03 & 0 & 0.01 \\
\hline Total other countries & 0.07 & & & & &
\end{tabular}

Ambitious TTIP

\begin{tabular}{|lccccccc}
\hline European Union & 0.48 & 0.11 & 0.26 & 0.03 & 0.07 & 0.02 & 0.05 \\
\hline United States & 0.39 & 0.04 & 0.23 & 0.06 & 0.06 & 0 & 0.03 \\
\hline Total other countries & 0.14 & & & & & & \\
\hline
\end{tabular}

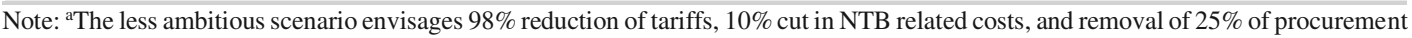
NTBs, whereas ambitious scenario models $100 \%$ elimination of tariffs, $25 \%$ cut in NTB driven costs, and $50 \%$ reduction of procurement barriers.Source: Francois et al. (2013, pp. 46, 82).

hard to quantify and model those spillovers, completely disregarded by some scholars (e.g., Felbermayr, Heid, et al., 2013; Felbermayr, Larch, et al., 2013), Francois et al. (2013 see Table 1), suggest that regulatory spillovers are likely to constitute not a negligible fragment of total welfare impact of a TTIP (i.e., 0.09 of $0.48 \%$ GDP growth for the EU, and 0.06 of $0.39 \%$ GDP growth for the USA in the ambitious scenario).

On the flipside, the regulatory agenda may also induce particular disadvantages or "negative spillovers" also overlooked in most quantitative modelling studies (Ciuriak \& Singh, 2015, p. 3; Narayanan, Ciuriak, \& Singh, 2015, pp. 2-3). Messerlin distinguishes PTA rules that redesign market conditions as "norm-setting." These rules set standards for technical, safety and other commercial and non-commercial purposes. Yet they may consequently inhibit market competition and charge higher costs than expected economic benefits especially for developing countries (Messerlin, 2008, p. 5). For example, higher standards for environmental protection, labour and/or IPRs embraced by PTA partners as well as countries that are in intensive commercial interaction with the partners may prove 
cumbersome because of needed industrial as well as executive, legislative and judiciary capacities to comply (Chauffour \& Maur, 2011a; Stoler, 2011, pp. 229-231). On the other hand, in some issue areas such as state-owned enterprises (SOEs), non-compliance with higher PTA standards may turn to an advantage for the third parties, which enjoy and strategically utilise a greater "policy space" to build and maintain a competitive edge in international market vis-a-vis PTA partners (Ciuriak \& Singh, 2015, pp. 8-9). In this respect, developing countries are in a position to assess a PTA also from a policy perspective, evaluate potential impact of rules in specific domains upon domestic reform agenda and ensure that sufficient autonomy is in place to pursue legitimate objectives such as poverty alleviation and transfer of technology (Chauffour \& Maur, 2011b, pp. 23, 34; Hoekman, 2011, pp. 9598, 102-104; Hoekman, Mattoo, \& Sapir, 2007, pp. 387-389).

Negative trade diversion impact of PTAs for the third parties can be alleviated further if parties adopt a methodology of "open regionalism," by embracing nondiscrimination through MFN-based liberalisation of NTBs and the use liberalised rules of origin (RoO) (Chauffour \& Maur, 2011a, pp. 2-3; Cottier et al., 2014, p. 6, 45). Liberalising RoO would particularly prevent segmentation of the PTA market from world markets by ensuring the feasibility of global sourcing of intermediate inputs (Ciuriak, 2014, pp. 6-8; Ciuriak \& Singh, 2015, p. 5).

\section{$3 \quad$ TRANSATLANTIC TRADE AND INVESTMENT PARTNERSHIP (TTIP)}

The TTIP negotiations follow a mandate set by the High Level Working Group on Jobs and Growth (HLWG) made of high-level officials from the United States and Europe (HLWG, 2013). Issues on the agenda can be listed under three somehow overlapping headings: market access, regulatory matters and rules. Accounting for the negotiation dynamics, one can further divide the issues into six clusters (shown in rows on Table 2) within which initial trade-offs to take place, to be followed by trade-offs between clusters (Messerlin, 2014, p. 6).

\subsection{Market access}

Expected welfare gains from TTIP will derive from additional access of transatlantic partners to each other's goods, services and government procurement markets. The area of goods promises the largest gains that would stem from trade and investment to be created by the removal of several TABLE 2 The map of TTIP negotiation agenda

$\begin{array}{llll} & \text { Market access } & \text { Regulatory matters } & \text { Rules } \\ \text { Goods } & & \\ \text { Industrial goods } & \text { Tariffs } & \text { Technical barriers to trade } & \text { IPRs: patents (pharma, chemicals) } \\ & \text { Rules of origin } & \\ & \text { TTIP safeguards } & \\ & \text { Tariff-equivalents } & \\ & \text { Subsidies }\end{array}$




\begin{tabular}{llll}
\multicolumn{1}{c|}{ Agri-food } & Tariffs & $\begin{array}{c}\text { Sanitary \& phytosanitary } \\
\text { measures }\end{array}$ & IPRs: geographical indications \\
& $\begin{array}{l}\text { Rules of origin } \\
\text { Tariff-rate quotas } \\
\text { TTIP safeguards }\end{array}$ & & \\
Services & Scope & Regulatory barriers & IPRs: copyright protection \\
& TTIP safeguards & Data protection & \\
Investment & Coverage & Regulatory barriers & Dispute settlement (ISDS?) \\
Public procurement & Coverage & & \\
Rules & Trade facilitation & Environment & Labour standards \\
& State-owned Enterprises & Small \& medium firms & Competition policy \\
& Localisation barriers & & Transparency \\
& Raw materials \& energy & & Institutional rules (dispute \\
& & & settlement etc.)
\end{tabular}

TABLE 3 Barriers to trade in goods and services compared

\begin{tabular}{|c|c|c|c|c|}
\hline & \multicolumn{3}{|c|}{$\begin{array}{l}\text { Simple average MFN applied tariff rates for } 2014 \\
(\%)\end{array}$} & \multirow{2}{*}{$\begin{array}{l}\text { Tariff equivalents of commercia } \\
\text { services barriers }(\%)^{\mathrm{a}}\end{array}$} \\
\hline & Non-agriculture & Agriculture & Total & \\
\hline Turkey & 5.4 & 42.2 & 10.7 & 43.9 \\
\hline EU & 4.2 & 12.2 & 5.3 & 8.5 \\
\hline USA & 3.2 & 5.1 & 3.5 & 8.9 \\
\hline
\end{tabular}

Source: World Tariff Profiles (WTO et al., 2015). ${ }^{\text {aCalculations }}$

of Haufbauer et al., 2012: 17.

barriers set at multiple levels in various sectors. Despite higher duties in some product categories such as motor vehicles, parts and components, processed food sector, and to some extent in agriculture, forestry and fisheries, applied tariff rates in industrial goods are generally at low levels and more than half of bilateral trade is carried out duty-free (Francois et al., 2013, pp. 14-15; see Table 3). In addition, Patrick Messerlin contends that ensuring gains from tariff liberalisation will require liberalised RoO, which seem unlikely given the difficulty of compromising two distinct systems (Messerlin, 2014, p. 7). The elimination of NTBs is likely to bring more substantial benefits than tariffs in the area of goods trade.

In the realm of trade in services, negotiators will target NTBs that hamper different modes of international supply of service products. HLWG recommended the negotiators to commit to the highest levels of opening recorded in recent European and American FTAs (HLWG, 2013, pp. 3- 5). Taking account of liberal nature of services on both sides and limited actual services opening in those past deals, Cottier et al. (2014, pp. 8, 85-86) contend that TTIP would add little to opening transatlantic 
markets. ${ }^{4}$ Impediments in terms of tariff equivalents are higher in the US market especially in financial and insurance services whereas European barriers are greater in communication, other business, construction and cultural services (see Figure 1). Moreover, the two sides have politically sensitive areas that will likely be exempt from any potential opening such as financial services, maritime and perhaps also air transport for the Americans, and audio-visual services for Europeans (Messerlin, 2015, pp. 10-11; Schott \& Cimino, 2013, pp. 15-16). Plus, cross-border transfer of data by US corporations is an ongoing concern for Europeans and might affect bargaining in services, which also cover e-commerce, digital products, e-signatures, online consumer protection and access to and use of the Internet (Lester, 2014, p. 2). Aside from the scope, the negotiators will have to reconcile past differences on the methodology of scheduling commitments probably upon a "hybrid" method that will synthesise positive and negative list approaches (Schott \& Cimino, 2013, p. 16).

Investment is another domain where corporations on both sides expect the removal of remaining obstacles to business establishment and operations. If the two sides can remove foreign direct investment (FDI) related regulatory barriers under a TTIP, this will lead more EU and US corporations to open affiliates and create additional employment on the other side. The investment impact of TTIP on third parties will be contingent upon the pattern of their economic ties with TTIP partners (Francois et al., 2013, pp. 92-93). Beside FDI liberalisation, transatlantic business community desires higher standards of investment protection in line with the rules of recent US PTAs and Bilateral Investment Treaties (BITs) (e.g., Donnelly, 2013). However, the fate of the proposed

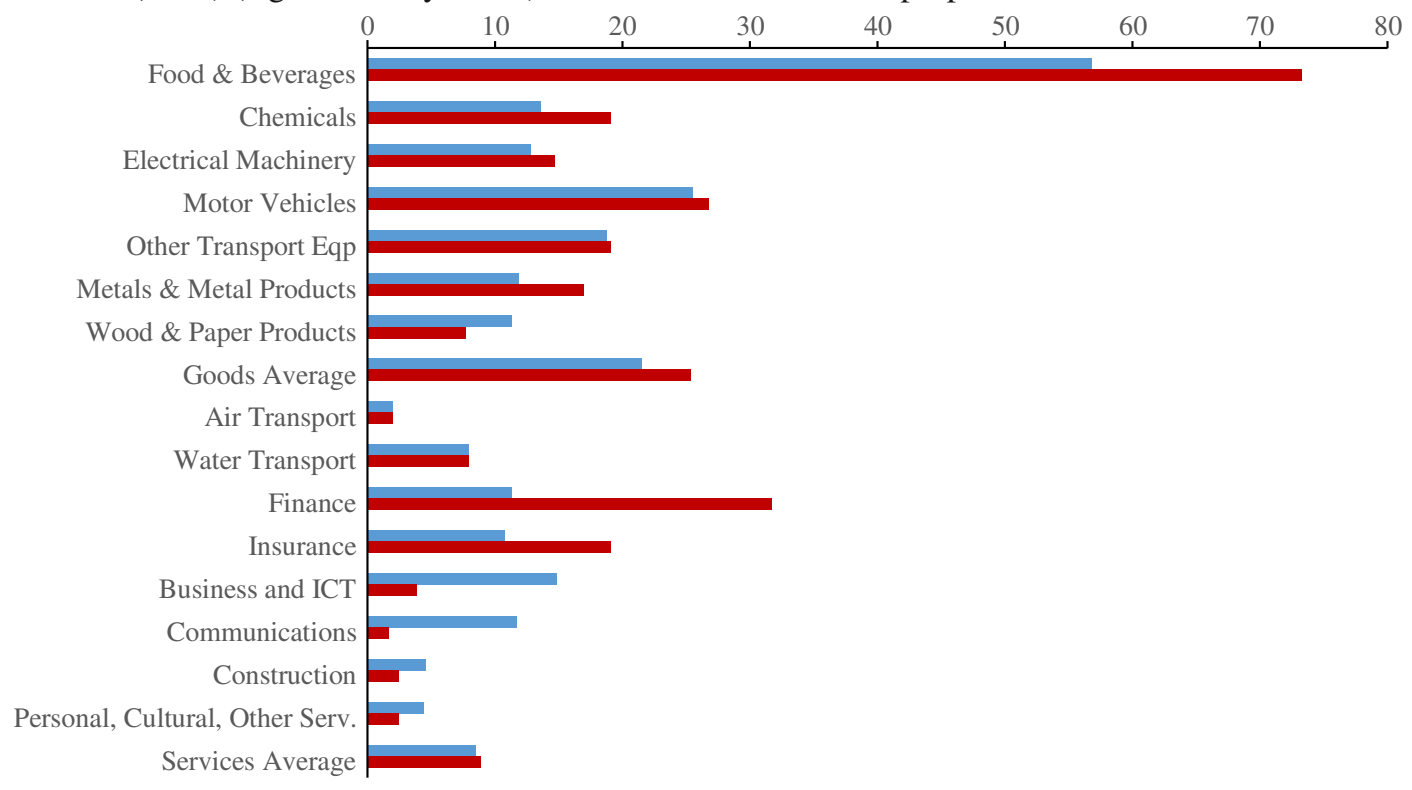

- EU NTBs Against USA $\square$ USA NTBs Against EU

FIGURE 1 Non-tariff barriers to trade in the US and EU

Source: Ecorys (2009)

\footnotetext{
${ }^{4}$ Unless indicated otherwise this section rests in the EU and US priorities explained in respective websites: http://ec.europa.e u/trade/policy/in-focus/ttip/ and https://ustr.gov/ttip (accessed 30 September 2016).
} 
Investor-State-Dispute Settlement (ISDS) tribunal is linked with the reconciliation of concerns of NGOs especially in Europe about potential negative social impact of enhanced investment protection and enforcement (EC, 2015b).

Government procurement is the last market access area significant mostly for the Europeans who seek dismantling discriminatory US restrictions enacted especially since the 2009 "Buy American" legislation (Schott \& Cimino, 2013, pp. 16-17). The final outcome will be determined by the US willingness to open up its markets especially at subfederal level beyond commitments granted under the WTO GPA (Schott \& Cimino, 2013, p. 17). The implications for partners and outsiders will depend on TTIP provisions on bidding thresholds and coverage as well as the impact of reciprocal liberalisation upon market access in particular good and service sectors.

\subsection{Regulatory matters}

In addition to regulatory barriers in services, transatlantic negotiators have been working on horizontal and sector-specific technical barriers to trade (TBT) in goods affecting manufacturing industries, and regulations on food safety, animal and plant health in the agri-food sector (i.e., Sanitary and Phytosanitary [SPS] measures). As seen in Figure 1, highest barriers bringing about additional costs for firms are in the food and beverages sector. In manufacturing, automobiles sector encounters higher costs up to an extra $25 \%$ tariff in addition to applied duties. Other transport equipment, chemicals and electrical machinery products face relatively significant NTB-related costs. However, even in the most ambitious scenario for a transatlantic FTA the negotiators will be able to address only half of NTBs that are "actionable," that is, NTBs that do not address geographical, cultural and other legitimate noncommercial concerns or purposes (Ecorys, 2009, p. xviii). The extent of trade/investment diversion as well as of positive spillovers will depend on the methodological approach for transparency, regulatory cooperation and convergence which could be through harmonisation, mutual recognition or more innovative means (Lester, 2014, p. 2; Messerlin, 2015, pp. 12-15).

\section{3 | Rules}

Transatlantic parties have also engaged in an encompassing standard-setting exercise that goes far beyond the WTO and previous PTAs. The success will depend on negotiators' capability to bridge regulatory differences. Inter alia, cooperation on integrating Small and Medium-Sized Enterprises (SMEs) into transatlantic trade as well as on customs and trade facilitation are two domains where negotiators would relatively easily reach an accord. Likewise, both Americans and Europeans are concerned about "new forms of anticompetitive policy and behaviour" set particularly by emerging economies which can be handled through WTO-plus disciplines for competition policy and localisation barriers (HLWG, 2013, pp. 5-6). Nevertheless, the parties will need to overcome significant disagreements on issues such as cross-border transfer of data, state aid and subsidies, as well as SOEs (Schott \& Cimino, 2013, pp. 9, 17-18). Despite greater differences in the domain of IPRs, TTIP is very likely to create a joint set of stringent rules to protect vested interests in knowledgeintensive and artistic industries both in Europe and the United States if negotiators exclusively focus on overcoming differences on critical areas addressed in their previous PTAs (Messerlin, 2014, p. 10; Schott \& Cimino, 2013, pp. 8, 10-11). For instance, both US and EU FTAs with Korea contain WTO-plus provisions that extend "effective period" of patent protection for the pharma and chemicals industries (Schott \& Cimino, 2013, pp. 8, 10-11). However, a prerequisite to a 
successful outcome might be the resolution of long-standing frictions surrounding geographical indications (GIs) (Lester, 2014, p. 2; Schott \& Cimino, 2013, pp. 11-13).

Transatlantic Trade and Investment Partnership is also likely to set a mixture of legally binding and nonbinding commitments to higher labour and environmental standards if negotiators can reconcile disagreements (Anuradha, 2011, pp. 409-420; Elliott, 2011, pp. 428-435). While in its past deals, the USA subjected these areas to dispute settlement mechanism, the European FTAs contained mostly non-binding rules and consultation mechanisms. Potential implications of binding mechanisms for developing countries are hard to predict, since there is no record of use of sanctions for the breach of social clauses that may require the suspension of concessions or financial compensation (Anuradha, 2011, pp. 416-420; Elliott, 2011, pp. 435-439).

\section{TURKEY AND TRANSATLANTIC ECONOMIES}

Existing modelling efforts provide an imperfect and partial picture surrounding the impact of a transatlantic FTA on Turkey. In a baseline scenario where Turkey remains outside a "tariff-only" transatlantic pact, Ifo Institute reports estimate that Turkey's welfare losses would reach $0.27 \%$ of its real GDP (and 2.5\% loss in a "comprehensive" deal) (Felbermayr, Larch, et al., 2013, pp. 6-7; Felbermayr, Heid, et al., 2013, pp. 28-30, 41). For the same "tariff-only" scenario, the World Bank predicts a more moderate welfare impact-up to US\$160 million annual loss to the Turkish GDP (World Bank, 2014a, p. 27). Modelling a "comprehensive" baseline scenario that takes into account the removal of NTBs and (direct) positive regulatory spillovers, Turkish Central Bank economists suggest a smaller negative impact on Turkey. If Turkey is left out of the deal they project only a modest loss ( $0.19 \%$ of Turkish GDP in the long run-around one thirteenth of the Ifo estimate). For a comprehensive "TTIP plus Turkey" scenario, the same study predicts that Turkish GDP will expand by $3.8 \%$ in the long term (Mavus, Oduncu, \& G€unes, 2013, pp. 9-10). There is no study taking into account of potential negative spillovers of a transatlantic agreement for Turkey.

With no doubt, the scope and structure of Turkey's trade and investment ties with the EU and the United States will have critical importance in determining potential implications of a transatlantic FTA for Turkish economy and policies. Turkey is economically and institutionally more integrated with the EU thanks particularly to the existing Customs Union in industrial goods. With the Customs Union, Ankara adopted the EU's Common Commercial Policy, unilateral preferential regime and Common External Tariff for industrial products. The treaty also stipulated Turkey to converge its domestic regime with the EU's acquis communautaire in TBT, IPRs and competition policies (Togan, 2015).

Since the inauguration of the EU accession talks in 2005, the Turkish government has also undertaken reforms to align domestic laws and regulations with the acquis in various policy domains. However, the pace of reforms has slowed down in the post-2008 crisis era in tandem with the government's initiation of a set of "selective" industrial policies to address specific structural challenges (Yilmaz, 2011). These ongoing challenges include large current account deficit, low productivity especially in the farming sector, and exports sophistication problem, particularly the inability of Turkey to expand the ratio of high-tech products within the national exports basket (Akman, 2012, pp. 145-151; Onis \& Kutlay, 2013, pp. 1415-1416; World Bank, 2014b, pp. 1- 30). The government has embarked upon a set of strategies together with a master plan called Vision 2023, 
which embraced the goal to make Turkey one of the top 10 economies worldwide by expanding GDP from US $\$ 790$ billion (in 2012) to US\$2 trillion by the year 2023, the centennial of the Turkish Republic (AKP, 2012, p. 54). These strategies encompassed government intervention to the market through state supports and incentives, localisation requirements and government procurement as well as trade policies. Inspired from the success of BRICs and other catch-up economies Turkish industrial policies have in fact been directed towards a "neo-developmentalist" route within the policy space remaining from international commitments, yet in contradiction with the emerging transatlantic commercial agenda, to be discussed later (Onis \& Kutlay, 2013, pp. 1420-1423; Yilmaz, 2011).

As a consequence of intensive economic integration, the EU has become Turkey's top trading partner whereas Turkey stands the fifth biggest export market of the Union. Thanks to market opening and reforms to the business environment following the Customs Union, the structure of the Turkish manufacturing base and exports have transformed from one producing heavily labourintensive and low technology products to an economy led by capital-intensive and medium technology products (WTO, 2016a, pp. 12, 20-21). Currently, Turkish manufacturing exports to the world are spearheaded by vehicle and transport products, followed by clothing, metal products, chemicals and machinery. In turn, Turkey imports mineral fuels, chemicals, machinery and automotive products as well as iron and steel. According to the WTO, intermediaries made up $46.3 \%$ of Turkish merchandise exports and 55.3 of the total imports in 2014. This signifies intensive intra-industry trade and investment links especially with Europe that have paved the way for the integration of Turkish firms with global value chains in major industries such as motor vehicles, textiles and apparel, and agri-food (World Bank, 2014a, p. 9, 2014b, pp. 40-52). Indeed, Turkish-EU trade is quite diversified and made up of a twoway exchange in various intermediary and finished goods (See Table 4). In manufacturing, Turkey predominantly exports automotive, clothing and machinery items, and imports chemicals, machinery and automotive products. In agriculture, Turkey registers a surplus with its exports of mostly dried, fresh and processed fruits and vegetables (amounting to US\$5.6 billion in 2014) in exchange for European oil seeds, food preparations,

TABLE 4 Major products in Turkey's trade with the European Union (2014)

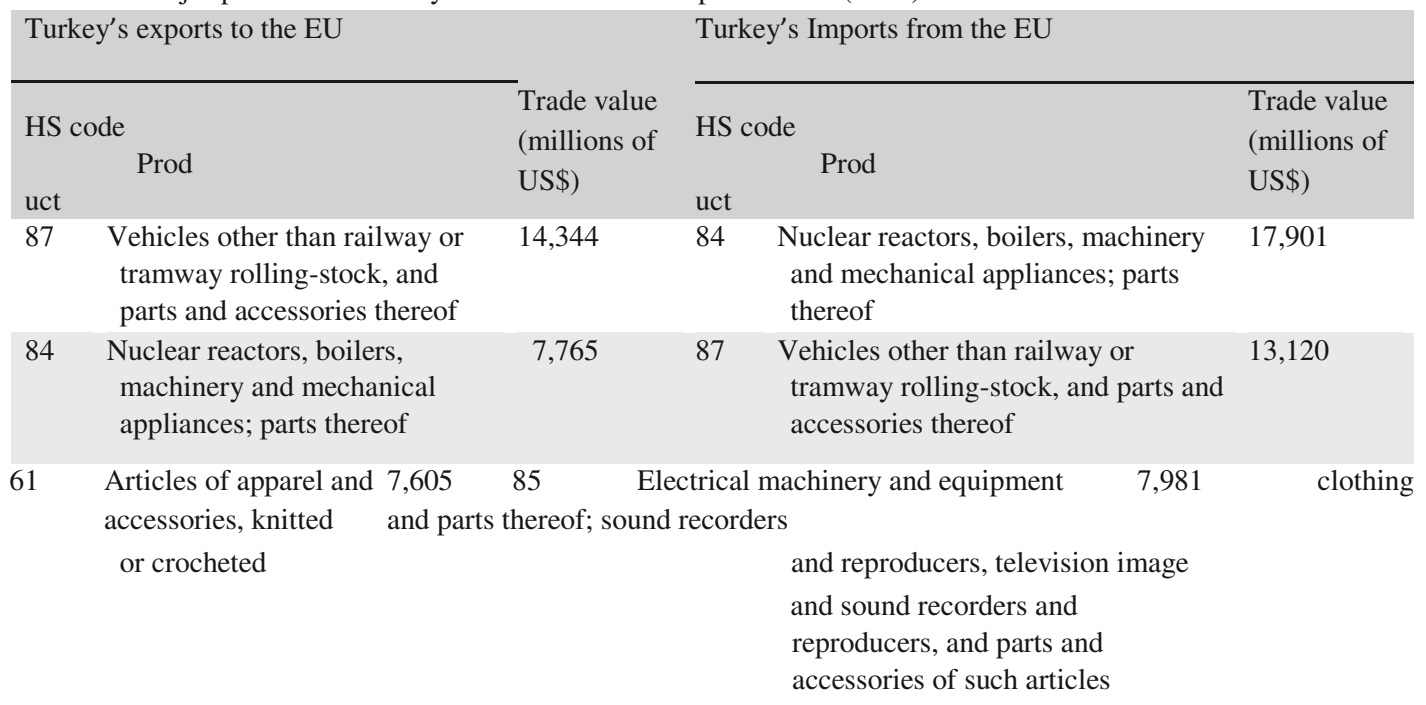


equipment and parts thereof; products of their distillation; sound recorders and reproducers, television image bituminous substances; mineral waxes and sound recorders and reproducers, and parts and accessories of such articles

62 Articles of apparel and $4,608 \quad 72 \quad$ Iron and steel clothing accessories, not knitted or crocheted

$\begin{array}{cl}73 & \text { Articles of iron or steel } \\ 39 & \text { Plastics and articles thereof } \\ 8 & \begin{array}{c}\text { Edible fruit and nuts; peel of } \\ \text { citrus fruit or melons }\end{array}\end{array}$

2,515 $39 \quad$ Plastics and articles thereof

6,570

2,500

2,158

30 Pharmaceutical products

90 Optical, photographic,

cinematographic, measuring, checking, precision, medical or surgical instruments and apparatus; parts and accessories thereof

\begin{tabular}{|c|c|}
\hline 40 & Rubber and articles thereof \\
\hline 72 & Iron and steel \\
\hline 63 & $\begin{array}{l}\text { Other made up textile articles; } \\
\text { sets; worn clothing and worn } \\
\text { textile articles; rags }\end{array}$ \\
\hline
\end{tabular}

$\begin{array}{ccc}76 & \text { Aluminium and articles thereof } & 1,461 \\ 20 & \begin{array}{c}\text { Preparations of vegetables, fruit, } \\ \text { nuts or other parts of plants }\end{array} & 1,453\end{array}$
76 Aluminium and articles thereof 1,461 nuts or other parts of plants

$\begin{array}{llll}1,663 & 29 & \text { Organic chemicals } & 2,285 \\ 1,620 & 88 & \text { Aircraft, spacecraft, and parts thereof } & 1,823 \\ 1,519 & 48 & \begin{array}{l}\text { Paper and paperboard; articles of } \\ \text { paper pulp, of paper or of } \\ \text { paperboard }\end{array} & 1,756 \\ & & \end{array}$

2,285

1,756

73 Articles of iron or steel

74 Copper and articles thereof

1,382

38 Miscellaneous chemical products

1,377

TABLE 4 (Continued)

\section{Turkey's exports to the EU}

\begin{tabular}{ll}
\hline HS code & $\begin{array}{l}\text { Trade value } \\
\text { (millions of }\end{array}$ \\
uct & US\$)
\end{tabular}

94 Furniture; bedding, mattresses, mattress supports, cushions and similar stuffed furnishings; lamps and lighting fittings, not elsewhere specified or included; illuminated signs, illuminated name-plates and the like; prefabricated buildings

27 Mineral fuels, mineral oils and products of their distillation; bituminous substances; mineral waxes

\section{Turkey's Imports from the EU}

\begin{tabular}{lll}
\hline HS code & Trade value \\
(millions of
\end{tabular}

$71 \quad$ Natural or cultured pearls, $\quad 1,376$ precious or semi-precious stones, precious metals, metals clad with precious metal, and articles thereof; imitation jewellery; coin 

and their derivatives; dyes, pigments and other colouring matter; paints and varnishes; putty and other mastics; inks

$\begin{array}{cl}54 & \begin{array}{l}\text { Man-made filaments; strip and } \\ \text { the like of man-made textile } \\ \text { materials }\end{array} \\ 60 \quad \text { Knitted or crocheted fabrics } \\ 71 \quad \begin{array}{l}\text { Natural or cultured pearls, } \\ \text { precious or semi-precious } \\ \text { stones, precious metals, metals } \\ \text { clad with precious metal, and } \\ \text { articles thereof; imitation } \\ \text { jewellery; coin }\end{array}\end{array}$

819

33 Essential oils and resinoids; perfumery, cosmetic or toilet preparations

788

62

Articles of apparel and clothing 706 accessories, not knitted or crocheted 34
Soap, organic surface-active agents, washing preparations, lubricating preparations, artificial waxes, prepared waxes, polishing or scouring preparations, candles and similar articles, modelling pastes, dental waxes and dental preparations with a basis of plaster

Source: UN Comtrade

manufactured tobacco, cattle and grains (US\$2.7 billion). The Turkish Central Bank data indicate that the EU has also been the primary source of FDI responsible for $70 \%$ of inflows to Turkey between 2004 and 2014.

Turkey's economic ties with the United States have been less diverse and outweighed by historically strong security and political relations. Bilateral relations suffer deep-rooted challenges affecting especially Turkish exports to the United States and US FDI flows into Turkey (SGA, 2012). ${ }^{5}$ Over the past decade, US-Turkish trade has grown at a slower pace than trade of the two parties with the world. The share of the United States within Turkey's goods exports has experienced a decline between 2000 and 2014 from $11 \%$ to $4 \%$ at the expense of increasing Turkish imports and trade deficit (see Figure 2). The USA was the sixth exports and the fourth imports partner of

${ }^{5}$ In 2012 Turkey exported 1,095 nonagricultural and 136 agricultural products to the EU; and 418 non-agricultural and 51 farm products to the USA. In terms of 6-digit HS classification these products constituted $95 \%$ of bilateral trade with each party (World Trade Organization, International Trade Center, United Nations Conference on Trade and Development, 2015, p. 165). 
Turkey’s Exports by Destination (values in US\$ Billion)

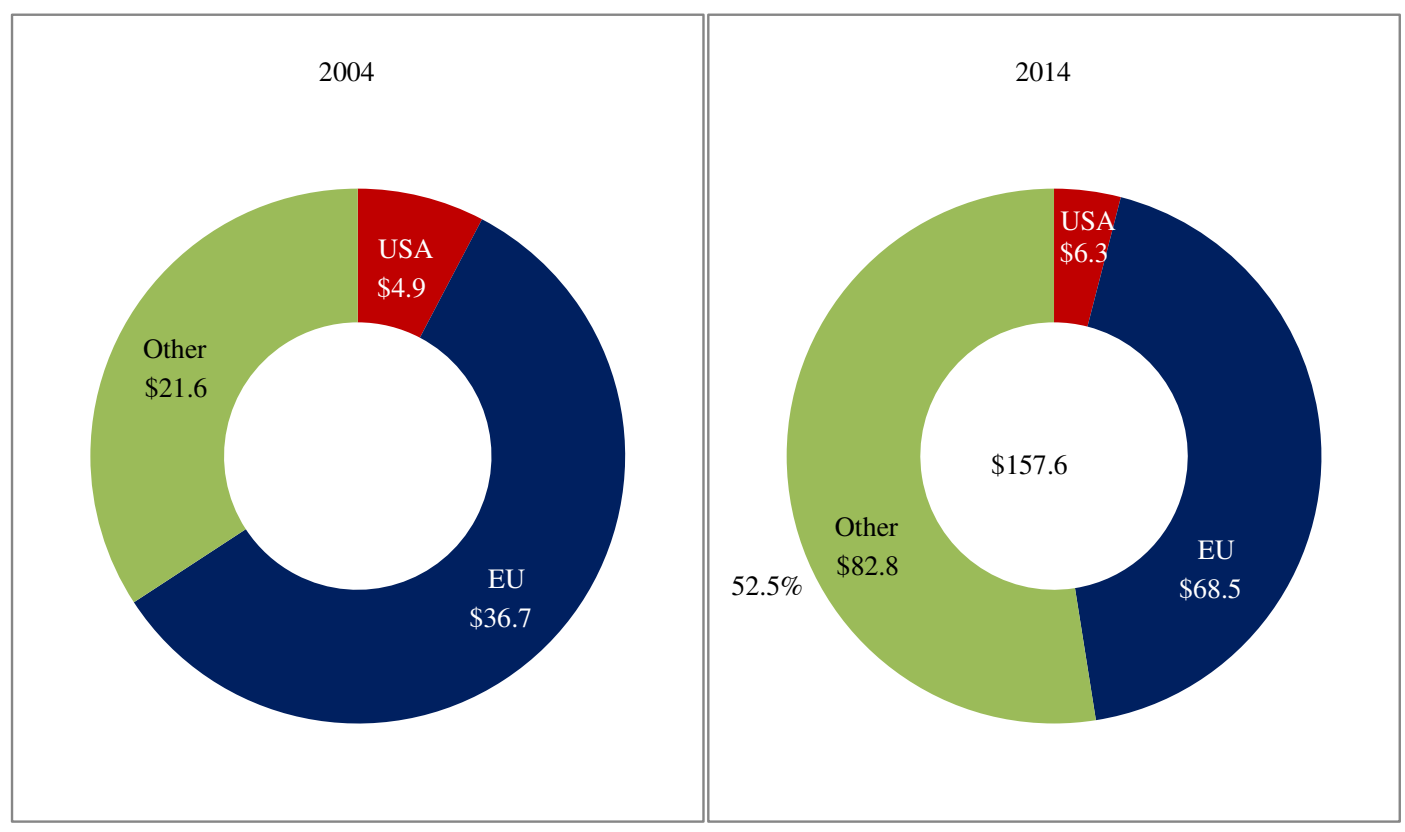

Turkey's Imports by Source (Values in \$Billion)

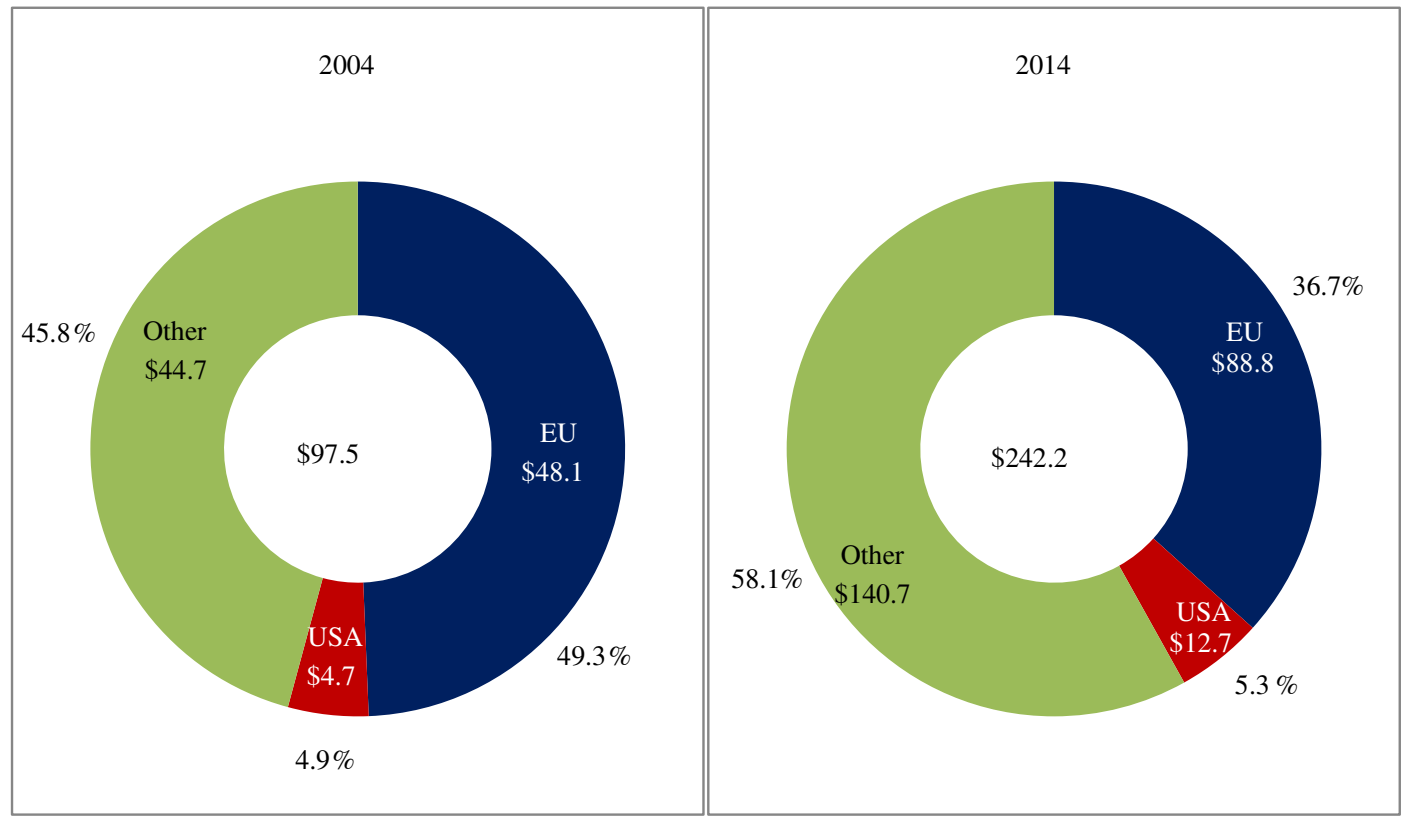

FIGURE 2 Trade with the USA and EU as share of Turkey's total trade Source: UN Comtrade

TABLE 5 Major products in Turkey's trade with the United States (2014)
Turkey's exports to the Turkey's imports from the 


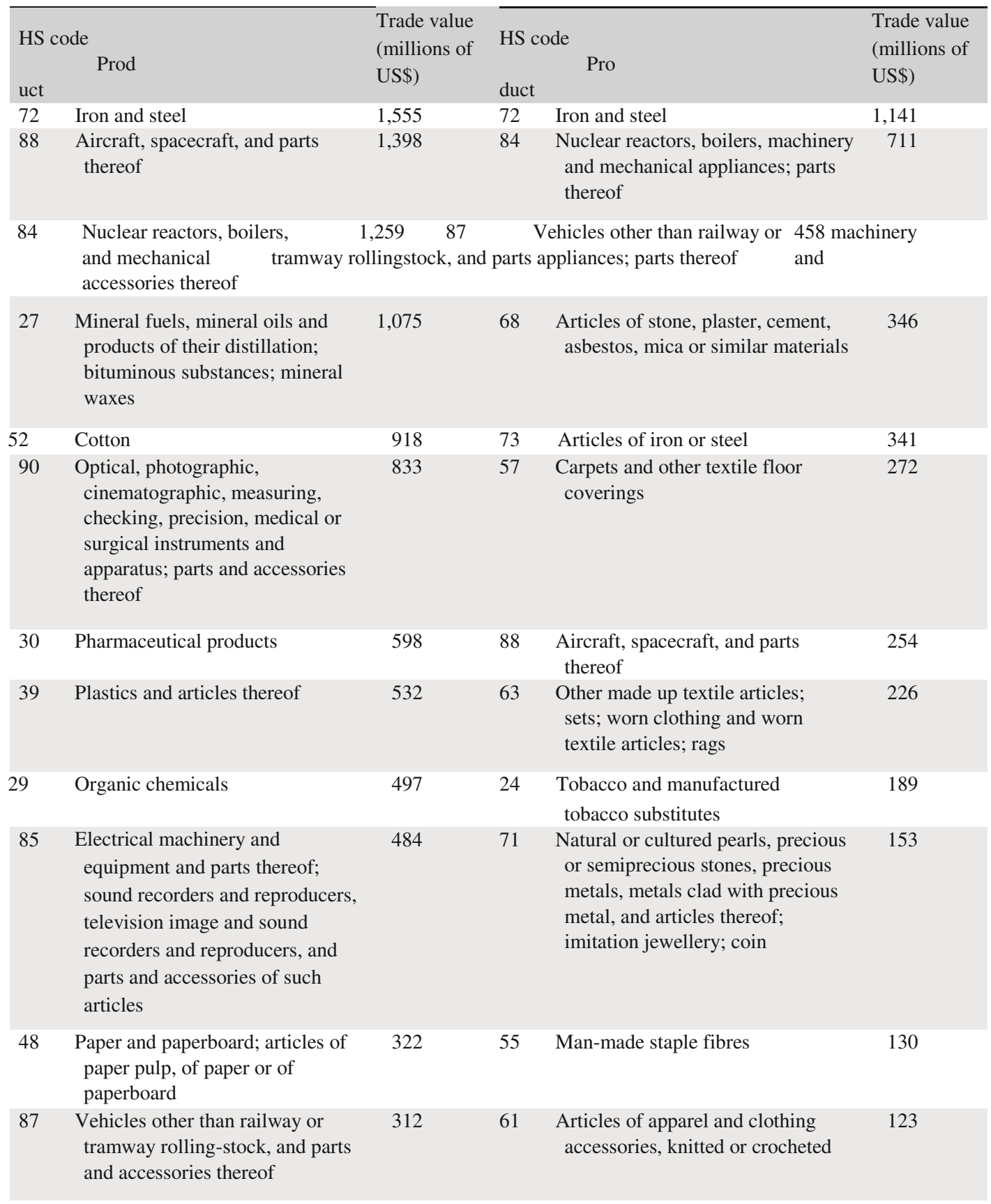

(Continues)

TABLE 5 (Continued)

\begin{tabular}{|c|c|c|c|}
\hline $\begin{array}{l}\text { Turkey's exports to the } \\
\text { United States }\end{array}$ & & $\begin{array}{l}\text { Turkey's imports from the } \\
\text { United States }\end{array}$ & \\
\hline $\begin{array}{l}\text { HS code } \\
\text { Prod }\end{array}$ & $\begin{array}{l}\text { Trade value } \\
\text { (millions of } \\
\text { US\$) }\end{array}$ & $\begin{array}{l}\text { HS code } \\
\text { duct }\end{array}$ & $\begin{array}{l}\text { Trade value } \\
\text { (millions of } \\
\text { US\$) }\end{array}$ \\
\hline
\end{tabular}



miscellaneous grains, seeds and fruit; industrial or medicinal plants; straw and fodder

\begin{tabular}{|c|c|}
\hline 23 & $\begin{array}{l}\text { Residues and waste from the food } \\
\text { industries; prepared } \\
\text { animal fodder }\end{array}$ \\
\hline 38 & Miscellaneous chemical products \\
\hline 99 & $\begin{array}{l}\text { Commodities not specified } \\
\text { according to kind }\end{array}$ \\
\hline 47 & $\begin{array}{l}\text { Pulp of wood or of other fibrous } \\
\text { cellulosic material; recovered } \\
\text { (waste and scrap) paper or } \\
\text { paperboard }\end{array}$ \\
\hline
\end{tabular}

62 Articles of apparel and clothing accessories, not knitted or crocheted fruit or melons
145

136

20

8

8 Edible fruit and nuts; peel of citrus fruit or melons

93 Arms and ammunition; parts and accessories thereof
27 Mineral fuels, mineral oils and products of their distillation; bituminous substances; mineral waxes

71 Natural or cultured pearls, Plastics and articles thereof precious or semi-precious stones, precious metals, metals clad with precious metal, and articles thereof; imitation jewellery; coin

Source: UN Comtrade

Turkey in 2014. Turkey's share in US trade is quite negligible, as it ranks number 26 among America's exports destinations and number 38 in its imports markets.

It is unquestionable that Turkish exporters, especially SMEs are unable to compete in the US market because they fail to meet American market requirements, particularly higher consumer expectations in terms of quality and customisation of products, as well as because of logistic and distribution costs, hard to meet without greater scale in exports. More importantly, Turkish exports to the US market are made up of labour and capital-intensive products, which do not match the US imports portfolio that is raw material and research intensive (i.e., petroleum and machinery) (McKinsey and Company, 2009; SGA, 2012, p. 15). Turkey exports (mostly final) products of iron and steel, passenger vehicles, textiles and clothing, machinery and building materials (See Table 5). It imports American intermediate goods (scrap iron and steel, chemicals, transport equipment), some high value-added products (aircraft, machinery and defence equipment) and mineral fuels and coal. In contrast to its trade with the EU, Turkey gives a growing deficit in its farming (as well as manufacturing) trade with the United States. Turkish firms export tobacco, confectionery, olive oil and fractions as well as dried fruits and vegetables (US\$675 million in ${ }^{6} 2014$ ). In turn Turkey imports

\footnotetext{
${ }^{6}$ Model BIT covers an extended scope of investment, stringent rules on host government performance requirements, disciplines on SOEs, and encompassing transparency obligations for publication of laws and regulations, policy decisions regarding
} 
nuts as well as cotton and soybeans, which are crucial inputs to Turkish textile and livestock sectors (US\$1 billion). In this respect, diminishing Turkey-US trade and growing trade deficit are structural challenges that require a more sophisticated export promotion strategy on Turkey's part that would address scale, quality and consumer taste issues as well as logistics and product-mismatch problems (McKinsey and Company, 2009; SGA, 2012). As will be discussed below the Turkish association with a TTIP (or negotiating a Turkish-US FTA) may not become the needed shot in the arm for Turkey's US-bound exports as much as it boosts imports unless accompanied with supplementary measures.

Part of the reason for less developed trade ties of Turkey with the USA is also because of less intensive investment linkages. According to Boston Consulting Group, Turkey has been "underinvested" by American multinationals and is far from attracting its "fair share" from US FDI outflows (Boston Consulting Group, 2011). Over the last 10 years, American investments in Turkey have reached an accumulated amount of US\$9 billion which constituted less than $6 \%$ of total average annual inflows. US businesses have ongoing concerns about the Turkish business environment owing to unpredictable policy decisions, sporadic changes to the regulations and legal system, judicial system inefficiency, red tape, high and inconsistent rates of taxes (Boston Consulting Group, 2011; USCS, 2014, p. 77). A viable policy option to relieve some of those concerns might be to upgrade the USTurkey Bilateral Investment Treaty (BIT) which was signed in 1985 along the lines of the first generation American BITs. Contemporary (fourth generation) US deals designed upon the "2012 Model BIT" provide a larger scope and higher standards of protection. ${ }^{7}$ Nevertheless, prior American attempts to update the agreement with Turkey have not been productive. ${ }^{7}$

Lastly, services trade is an under-explored area with regard to its part in Turkey's relations with the transatlantic economies. According to the WTO data for trade in value-added, services constituted $65 \%$ of Turkish GDP, $54 \%$ of added value of total goods exports and $38 \%$ value of Turkish exports of manufactures in 2014. The same year Turkish services exports amounted to US\$50 billion almost twice of Turkey's imports from the world (i.e., US\$23 billion). The Turkish exports have specialised in domains typical for middle-income countries, such as transport and tourism (which made up 88\% of Turkish services exports in 2014), but Turkey failed to build up satisfactory capacity in more sophisticated areas such as financial, IT or professional services (World Bank, 2014b, pp. 55-56). On the other hand, major service categories imported in 2013 included transportation services (especially maritime and road freight) of US $\$ 9.5$ billion value followed by travel (US $\$ 4.8$ billion), other business services (US\$2.56 billion), insurance (US\$1.75 billion), government (US\$1.7 billion) and financial services (US\$1.3 billion). As in trade in goods, Europe has also been the leading trade partner of Turkey in services with a Turkish surplus thanks largely to tourism. ${ }^{8}$

investment and arbitration proceedings. See https://ustr.gov/sites/default/files/BIT\%20text\%20for\%20ACIEP\% 20Meeting.pdf (accessed 1 September 2016).

${ }^{7}$ According to a confidential cable from the US Embassy in Ankara to Washington DC dated August 13, 2008 released by Wikileaks previous US attempts failed because of the unwillingness of Turkish government officials to undertake additional commitments https://www.wikileaks.net/cable/2008/08/08ANKARA1450.html (accessed 1 September 2016).

${ }^{8}$ The European Commission (EC) indicates that in 2013 Turkey exported EUR 15.4 billion value of services to the EU in turn for EUR 10.5 billion value of imports. http://ec.europa.eu/trade/policy/countries-and-regions/countries/turkey/ (accessed 15 September 2016). 


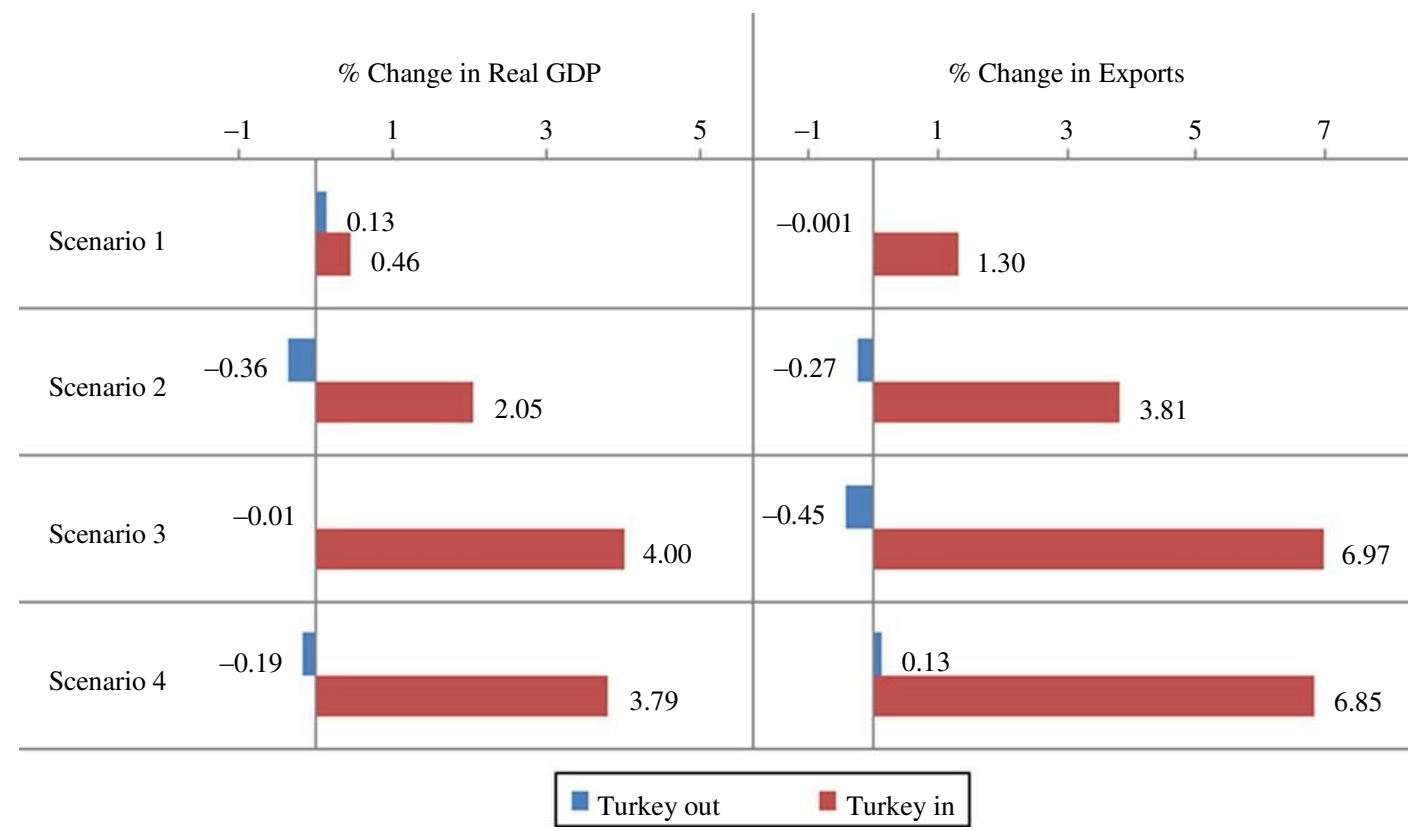

Scenario 1: Tariff-only

Scenario 2: Tariff + Moderate NTB Reduction (5 Per Cent Cost Reduction in Service Barriers, 2 Per Cent Reduction in Other Sectors)

Scenario 3: Tariff + Comprehensive NTB Reduction (5\% Cost Reduction in All Sectors)

Scenario 4: Tariff + Comprehensive NTB Reduction + Direct Spillover Effects (20\%)

FIGURE 3 Impact of TTIP on Turkish real GDP and exports

Source: Mavus et al. (2013)

\section{TURKEY AND THE TRANSATLANTIC MARKET ACCESS AGENDA}

The structure of remaining tariffs and NTBs affecting Turkey's trade with transatlantic parties will determine the potential economic benefits of TTIP. Starting with the market access agenda of TTIP for goods, tariffs remain a significant issue area as much as NTBs with respect to implications for Turkey.

\section{1 | Tariffs}

The majority of Turkish export products enter both US and European markets duty-free thanks largely to the Customs Union and the USA's Generalized System of Preferences programme. ${ }^{9}$ In case of the European market, high tariffs remain an obstacle for Turkish exporters of some products such as pasta, olive oil, hazelnuts and confectionery. Tariffs of the United States concern Turkish exporters of

\footnotetext{
${ }^{9}$ Overall, $100 \%$ of Turkish exports in non-agriculture goods and around $81 \%$ value of farming products already enter European markets duty-free. Similarly, $77 \%$ of Turkish farm exports and approximately $72 \%$ value of nonagriculture exports enter the US duty-free (2013 figures as published in WTO et al., 2015, p. 166).
} 
tobacco, alcoholic beverages, textiles, garments, shoes, dairy, fruits and vegetables (MoE, 2015, pp. 3,12 ). On the flipside, Turkish tariffs constitute a significant barrier for both US and European exporters of farm products (See Table 3 above). Three-digit tariff peaks cause complaint for the exporters of meat, live animals and dairy products to Turkey (WTO et al., 2015, p. 166, WTO, 2016a, pp. 53-54). US exporters also complain about high applied duties for fresh and processed fruits, vegetables and derivatives, footwear as well as alcoholic beverages and tobacco products (USTR, 2016a, pp. 426-427).

The removal of tariffs in a baseline scenario will benefit the US exporters of industrial goods who will freely release their products onto the Turkish market via the Customs Union with no need to a reciprocal concession to be granted to Turkey's exporters. In the case of Turkey's exclusion, studies expect negligible or minor impact on Turkish exports irrespective of the level of ambition of the deal between the US and the EU. For example, the World Bank study anticipates a modest growth in total Turkish exports $(0.02 \%$ growth) in a tariff-only baseline scenario, with moderate annual gains in most product groups but motor vehicles and parts that would register a slight fall (0.75\%). Mavus et al. (2013) differently suggest that in a tariff-only baseline scenario Turkish exports would register no increase but rather a negligible loss, which would get larger if the deal covers NTBs (when positive spillovers discounted) (see Figure 3 above).

On the other hand, both tariff-only and comprehensive "TTIP plus Turkey" scenarios will clearly mean Ankara's granting of significant concessions in terms of tariff cuts (especially in farming) in turn for much lower counter tariff concessions from the EU and USA (and no reductions in farm subsidies). The World Bank forecasts a modest annual export increase for Turkey in a tariff-only deal. Textiles and garment exports are to record an annual increase of more than $4 \%$ yet at the expense of $1.5 \%$ falls in exports of both automotive and vehicle product categories (World Bank, 2014a, p. 102). As outlined in Figure 3, Mavus et al. (2013, pp. 9-10) expect Turkey's association to lead to an expansion to the Turkish exports between 1.30 (for tariff-only scenario) and 7\% (for "tariff + NTBs" scenarios) depending the coverage of the transatlantic deal. In other words, it is very likely that the removal of tariffs will boost the Turkish imports especially in farming due to higher Turkish protection whereas potential export gains from "TTIP plus Turkey" scenarios rest mostly in the removal of NTBs rather than tariffs.

\subsection{NTBs affecting manufacturing industries}

In manufacturing, TTIP is likely to affect a number of Turkish NTBs falling in the category of TBTs, a regulatory domain highly harmonised with the EU's acquis. Turkey's import licensing regime seems to be the number one outstanding issue to be subject to discipline in case of a Turkish re-engagement through TTIP. Import restrictions especially licenses that affect Turkey's imports of second-hand products as well as alcoholic beverages are supposedly in breach of even the CU commitments of Turkey (EC, 2015a, p. 34; USCS, 2014, pp. 68-72). The United States is also critical of Ankara's implementation of the EU's "CE mark" that certifies products' conformity to European technical standards, but that is reportedly applied by Turkish authorities in discrimination of US exports bound to Turkey (USCS, 2014, p. 64). Finally, the healthcare sector is where a substantial part of transatlantic concerns is placed. A further convergence with the transatlantic standards is likely to erode outstanding flexibilities that allow the government to place measures to constrain the budgetary burden created by the universal healthcare system. Good Manufacturing Practice (GMP) certificate 
requirements, the Turkish public reimbursement system (which undercuts prices of healthcare supplies) and insufficient IPR protection for test data of drugs are among problems raised frequently by transatlantic governments (WTO, 2016b, pp. 40-41; USTR, 2014b, p. 100).

On the flipside, Turkey will likely benefit from a TTIP with no need for association if US and EU negotiators remove (on an MFN basis) some of outstanding TBTs in the transatlantic marketplace which are also critical to Turkish exporters. Any non-discriminatory dismantling of NTBs outlined in Figure 1 has a potential to benefit also Turkish export firms which operate in automotive, machinery, chemicals and other industries. For the US market, the Global Trade Alert (GTA) database more specifically suggest that Turkish suppliers are affected by US business and licensing regulations as well as TBTs for energy conservation and labelling standards in machinery, transport and telecommunication equipment sectors (also SGA, 2012, pp. 20-21). ${ }^{10}$ Despite the Customs Union, outstanding impediments persist in Europe such as long-lasting licensing procedures for Turkish drugs owing to GMP requirements, public safety regulations for chemicals, biocides and cosmetics; and sector-specific measures such as Registration, Evaluation and Authorisation, and Restriction of Chemicals (REACH), (MoE, 2015, pp. 14-16).

\subsection{NTBs affecting the agri-food sector}

In contrast to technical standards, Turkey's concord with European food safety, veterinary and phytosanitary policy is at an early stage (EC, 2015a, pp. 44-45). This fact, disregarded by existing studies, will significantly limit expected benefits from market opening in the agri-food sector as it concerns both market access conditions of Turkish exporters and Turkey's imports regime. Owing to poorer domestic standards, Turkish exporters face SPS measures as a barrier to access the European market for dairy, nuts, fruits, vegetables and poultry products and to the US market for agrifood, cosmetic products and medical equipment (MoE, 2015, pp. 5-6, 12-16; World Bank, 2014a, p. 61; Milliyet, 18 September 2013). Unless Turkey invests substantively in rural infrastructure to meet transatlantic standards in near future, it is unrealistic to expect the realisation of any increases to Turkish exports in fruits, vegetables and processed food forecasted by existing studies (e.g., Eruygur, 2012; van Leeuwen et al., 2011; World Bank, 2014a, pp. 64-66). To meet transatlantic SPS norms, Ankara faces a challenge much bigger than the costs it had encountered while implementing the Customs Union commitments over the past two decades (estimated as EUR 1 billion in 2009 figures, Togan, 2015, p. 44). ${ }^{11}$ On the imports side, in any mechanism that would further engage Turkey with transatlantic economies in farming (e.g., TTIP or modernisation of the Customs Union) Ankara will be in a situation to remove outstanding SPS-related measures it had long placed to protect the farming. Those measures criticised for noncompliance with international standards do arguably hinder particularly meat and animal imports from Europe and the USA (EC, 2015a, p. 45; USTR, 2014a, p. 87). Overall, existing studies expect the liberalisation of farming to boost Turkish imports of especially

\footnotetext{
${ }^{10}$ Available at http://www.globaltradealert.org/ (accessed 15 September 2016).

${ }^{11}$ According to the World Bank (2010, p. 7) Turkey needs to invest EUR 2 billion to modernise food enterprises in dairy, fish, meat and livestock by-products to catch up with European standards.
} 
cereals and oilseeds as well as livestock products (especially cattle and bovine meat) in addition to creating rural unemployment. ${ }^{12}$

\subsection{Barriers to investment and services}

No study has been conducted to evaluate the impact of a transatlantic FTA on FDI flows into/from Turkey. Nonetheless, it seems clear that investment creation between the USA and EU may come at a cost of diversion of investment flows off the third parties including Turkey. Turkey's joining TTIP or engaging in a flanking agreement with the USA that would cover investment (i.e., a Turkish-US FTA or a renewed BIT) may offset potential diversion yet at a cost of removal of remaining NTBs in the Turkish market. Despite being a top investment climate reformer within the OECD group, Turkey has left in place regulatory barriers especially in service sectors such as maritime and air ( 0.575 each), radio and TV broadcasting, transport (0.383), media (0.2) and natural resource-based (primary) sectors (0.013) (0 signifies full openness and 1 represents full closeness of the sector upon regulatory restrictiveness indicators of the OECD). ${ }^{13}$ Turkish NTBs are comparatively higher than restrictions in the United States in real estate, accounting and auditing, tertiary (services) sector and business services. In case of a re-engagement in the area of investment, Turkey will need to commit to higher standards for protecting investors, which will probably be enforced through an ISDS tribunal.

Other than outstanding barriers to FDI, Turkish services market is not as open as transatlantic economies also because of regulatory barriers affecting cross-border services supply. As per calculations of Hufbauer, Jensen, and Stephenson (2012, p. 17), average tariff equivalents of commercial services barriers in Turkey are on average five times higher than those of the United States and the EU (See Table 3). As seen in Figure 4 the impediments in commercial services take shape of administrative procedures, exclusivity of rights and Turkish citizenship requirements, and these are particularly larger in the area of professional services (i.e., legal, accounting, auditing and other categories) where the USA and EU have strong offensive interests (also USTR, 2016a, p. 428). In addition, both the USA and EU have offensive interests also in other areas. During the Doha services talks, which paved the way for TiSA negotiations in Geneva, both the USA and EU requested concessions from Turkey in computer and related services, postal and delivery, telecommunications, environmental, financial and energy services. The USA has been a requester also in audio-visual and education services, while the EU demanded further opening to the Turkish maritime transport sector (Marchetti \& Roy, 2013, p. 17). Recent escalation of legal restrictions on the access to Internet in Turkey as well as the Turkish privacy regime which constrains cross-border data transfer have also been on the American radar (USTR, 2016a, p. 429).

Given the lack of sufficient data and analysis on Turkey's trade in services Ankara's offensive and defensive interests can only be sketched by looking into statistics and the Turkish negotiation position during Doha/Geneva talks. In addition to tourism and travel services, in which Turkey became the top eighth exporter globally in 2013 and 2014 (the EU taken as a single entity), Turkey has also built up competitive capacity in the construction industry, the only area where Ankara became a requester during the WTO services talks (Marchetti \& Roy, 2013, p. 17). According to the data of the Turkish

\footnotetext{
${ }^{12}$ The World Bank estimates that extending the Customs Union obligations to farming will lead up to $3.25 \%$ decrease in total rural employment by 2018 (World Bank, 2014a, pp. 64-65, 125).

${ }^{13}$ Available at http://www.oecd.org/investment/fdiindex.htm (accessed 30 September 2016).
} 
Ministry of Economy annual project value of Turkey's contractors increased from US $\$ 2.5$ billion in 2002 to US\$33 billion in 2013, with a rise from 137 to 406 in the annual number of international projects. ${ }^{14}$ Nevertheless, during the Doha/Geneva talks, the EU and USA have also been requesters in construction services, and there is no NTBs identified in the transatlantic markets that the Turkish government could seek concessions in the context of a TTIP or TiSA (Marchetti \& Roy, 2013, p. 17).

Turkey has also built up a significant export capacity in personal, cultural and recreational services (ranking 3rd globally in 2014), insurance (ranking 10th) and transportation services (ranking 11th) (WTO, 2015, pp. 131-145). Turkey may not have a comparative advantage in each of these domains vis-a-vis European economies and/or the United States as it has become a net importer of insurance and financial services. Furthermore, exemption of audio-visual services from TTIP or TiSA negotiations as advocated by Europeans might constrain any potential benefits in personal, cultural and recreational services. Still Turkey may leverage a "TTIP plus Turkey" process (in

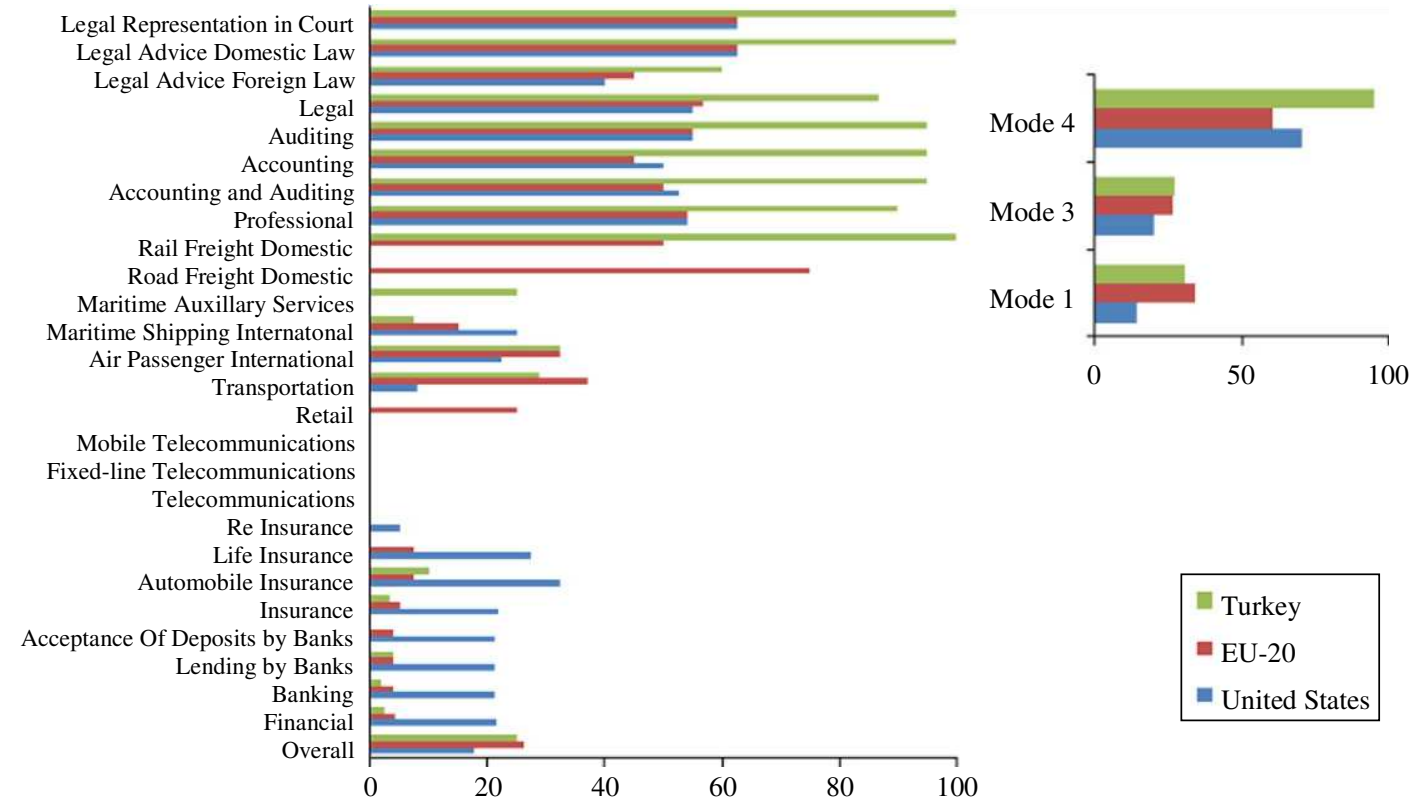

FIGURE 4 Regulatory barriers to services compared

Note: The index scores key restrictions on a 5-point scale between 0 indicating "open without restrictions" and 100 that represents "completely closed"

Source: Services Trade Restrictions Database, World Bank

parallel with the TiSA talks) to alleviate existing visa procedures that restrict the mobility of Turkish natural persons (Mode 4) as well as road quotas and transit permit procedures in Europe (World Bank, 2014a, pp. 50-55, 77-81; MoE, 2015, pp. 8, 17-18). Finally, it should be reiterated that Turkey will probably assume new liberalisation commitments at the end of the TiSA talks in Geneva and/or during the services talks for the modernisation of the Customs Union with the EU. Therefore, a "TTIP plus

\footnotetext{
${ }^{14}$ Data from the website of the Ministry of Economy http://www.ekonomi.gov.tr (accessed 1 September 2016).
} 
Turkey" scenario per se may not bring about a significant impact on services trade between Turkey and Atlantic economies.

\subsection{Government procurement}

The Turkish public procurement market presents lucrative opportunities for US and EU bidders thanks largely to grand infrastructure projects undertaken or projected by the central and local public authorities. The Turkish Public Procurement Authority reports that domestic market covered by the Public Procurement Law (PPL) amounted to US\$46 billion in $2014 .{ }^{15} \mathrm{In}$ fact, foreign bidders are ruled out from an actually even broader market due to ongoing derogations and sector-specific exemptions from the scope of the PPL (e.g., in military, housing and utilities sectors). High minimum thresholds and price advantages that favour local suppliers further extend discrimination against European and American suppliers (WTO, 2016a, p. 111; USCS, 2014, pp. 10-11). According to the US government, civilian offsets recently introduced to encourage technology transfer do contradict with the WTO's GPA, and as per the EC, these measures breach the EU acquis (USCS, 2014, p. 86; EC, 2015a, pp. 37-38). Foreign bidders also complain about tender processes for the complexity of requirements, lack of transparency and their vulnerability to political influence (USCS, 2014, p. 3, 93).

In case of the Turkish association with a TTIP, domestic industries will face competition in domestic procurement markets but they will also enjoy business opportunities in the transatlantic markets. Although transatlantic governments have been pressuring for Turkey's accession in the GPA, Turkish policymakers have long been adamant not to concede to demands for liberalisation of domestic regime. Key concerns have been a potential worsening of Turkey's current account deficit and risk of national suppliers' losing of internal market to foreigners (TOBB, 2013, pp. 2-3). There are also Turkish industry representatives who perceive opportunities in international markets, which could be tapped if Turkey guarantees reciprocal concessions (TOBB, 2013, pp. 3-4). This unstudied argument might particularly be valid for suppliers in internationally well-performing industries like construction. GTA reports that US "Buy American" requirements have also harmed Turkish suppliers of iron, steel and textiles whereas selected Turkish goods in aerospace industry and biofuel plants have been hit by American bail out/state aid measures. The government reports that Turkish procurers face barriers also in some EU countries like Italy since public procurement has been out of the scope of the Customs Union (MoE, 2015, p. 18).

As in the case of services, liberalisation and new disciplines on government procurement might have positive and negative implications for domestic industries, yet TTIP per se is unlikely to have a significant market access impact. This is because the issue is already on the agenda of Customs Union modernisation and Turkey has long been under pressure to accede the GPA. Plus, new disciplines in this area need to be analysed also for their impact on Turkey's development policies, discussed below.

\section{TURKEY AND THE TRANSATLANTIC RULES AGENDA}

The implications of the TTIP rules for Turkey require a multifaceted and comparative assessment of Turkish domestic standards and the transatlantic norms in the making, as well as their policy

\footnotetext{
${ }^{15}$ Details available at http://www.ihale.gov.tr/ (accessed 30 September 2016).
} 
repercussions. In the Turkish case, two parameters need to be incorporated into the analysis. First, Turkey sits in a unique position vis-a-vis most other third parties as it has already harmonised (because of the Customs Union), or is in the process of harmonising, a substantial portion of its domestic regulatory structure (because of the EU accession). Second, Turkey has adopted a "neodevelopmentalist" policy agenda in the post-2008 period with instruments aimed at boosting exports, curbing imports and diversifying local manufacturing towards higher technology products. ${ }^{16}$

Considering Turkey's development level and unique position vis-a-vis the EU, the "procompetitive" agenda items on the TTIP negotiation table can be listed as competition policy, subsidies, trade facilitation and government procurement. As Turkey has already aligned most of its domestic legal regime with the EU acquis, new rules in these domains are likely to yield more economic benefits to Turkey than compliance costs in the form of enhanced domestic competition and efficiency. Yet those benefits need to be assessed together with internal policy implications of transatlantic norms which may require amendments to "anti-competitive" regulations and practices. The TTIP agenda entails crafting of new pro-competitive disciplines particularly in the context of "new forms of anti-competitive policy and behaviour" (i.e., rules on SOEs, localisation barriers and competition policy and/or subsidies).

Those disciplines are likely to be in conflict with a number of domestic measures. Transatlantic governments have specifically been critical of Turkish state aid regulations, SOEs (e.g., the Turkish Grain Board) and intervention of these entities in prices of wheat and sugar, government's incentives for investors especially in free zones and for producers of renewable energy (EC, 2015a, p. 33, 41, 47; USTR, 2016a, p. 428; WTO, 2016b, pp. 35-36, 54, 121,

140). Besides, the liberalisation of Turkey's natural gas sector, particularly the privatisation of the state-owned pipeline company BOTAS has been up on their agenda (EC, 2015a, p. 33; USTR, 2016a, p. 428). Ongoing deficiencies regarding trade facilitation often pronounced by European and US governments include Turkey's weak customs enforcement capacity for IPRs, and misuse of import surveillance measures, efficiency and other problems about the modernisation of the customs (EC, 2015a, pp. 41, 79-80; USCS, 2014, pp. 19-21, 54, 235-237). Finally, transatlantic governments are concerned about the 2014 amendments to the Turkish PPL, which introduced an offset instrument by creating a mandatory $15 \%$ price preference in favour of local bidders to incentivise internal production of medium and high technology industrial products (e.g., for medical devices and commercial aircrafts) (EC, 2015a, pp. 37-39; USCS, 2014, pp. 79-80; USTR, 2016a, pp. 427-428). Removal of this market-distorting measure might yield positive efficiency effects but at a cost of a definite shrinking of the policy space utilised for technological upgrade of domestic manufacturing. Since most of these complaints stem from outstanding obligations of Turkey because of the Customs Union or EU accession process, a "TTIP plus Turkey" scenario will require Turkey to speed up reforms to further upgrade national standards to the EU level before the materialisation of a potential membership.

\footnotetext{
${ }^{16}$ These instruments were put into effect parallel to an Industrial Strategy Document issued in 2010, the Exports 2023 Strategy declaration and a sophisticated investment incentive package launched in 2012 in tandem with an Input Procurement Strategy (GITES), which aims to secure sustainable domestic supply of critical inputs and raw materials to Turkish manufacturing (Onis \& Kutlay, 2013, pp. 1420-1423).
} 
On the downsides, "norm-setting" areas that risk imposing higher costs than economic benefits for Turkey seem to be labour and environmental standards as well as IPRs and SPS-related rules, discussed before. According to Narayanan et al. (2015, p. 16) upper middle-income countries like Turkey will encounter modest costs (i.e., negative spillovers) to comply with higher standards set by the mega regionals. For a country in economic development level of Turkey the authors expect $1.65 \%$ increase in real labour costs and $0.16 \%$ growth in real capital costs by the year 2030 due to higher ecological standards imposed by Trans-Pacific Partnership and TTIP. ${ }^{17}$ Considering the fact that Ankara is already obliged to fulfil a longer to-do list for the EU accession, labour and environmental standards might particularly become problematic especially in a "TTIP plus Turkey" scenario that would impose more stringent social standards through effective enforcement mechanisms.

In case of environmental norms, and social policy and employment rules Turkey is "moderately prepared" in according with European standards (EC, 2015a, pp. 51, 76). Although Turkey has committed to core International Labour Organisation standards there are ongoing problems such as the rights of unregistered Turkish working force (34\% of total employment); the problems and conditions of subcontracted workers; child labour; and gender equality in employment terms (EC, 2015a, pp. 51-53). In the area of environment, the Europeans are concerned about the exemptions in national procedures regarding the Environmental Impact Assessment that supposedly distorts competition; and the inadequacy of public participation and access to information and justice, which supposedly affects investment disputes pertinent to environment (EC, 2015a, pp. 76-77). The European Commission is also closely monitoring Turkey's contribution on greenhouse gas emission reduction targets to 2015 Paris Climate Agreement (EC, 2015a, p. 78). Turkey will need to handle some of these challenges, if not all, in case of an association scenario depending on the level and nature of transatlantic standards in the making.

With respect to IPRs, Ankara's alignment with European standards is at an "advanced" level but Turkey has capacity challenges to enforce them. Because of the Customs Union, Ankara embraced the EU's regime on patents, copyrights, GIs etc. as well as WTO-plus disciplines for "data exclusivity" against the unfair use of test data of drugs. Nevertheless, American stakeholders are concerned with ongoing copyright, online piracy, and counterfeit goods problems, and widespread use of unlicensed software in Turkey (USTR, 2016b, p. 56). Ankara has long been on the infamous "Watch List" of the Office of the USTR. Likewise, a recent EC report named Turkey as the third most prominent source of counterfeit products crossing EU customs (EC, 2013, p. 34). Turkey is expected to legislate a new law to bring about deterrent criminal sanctions, and stronger civil, criminal and administrative procedures to combat piracy and counterfeiting internally and at the borders (EC, 2015a, p. 40-41; USTR, 2016b, p. 56; WTO, 2016b, pp. 44-47, 137). The government also has to enact new laws on industrial property and copyrights to catch up with the amendments to the EU regime (EC, 2015a, p. 40-41).

In addition to implementation costs, a TTIP-driven IPR agenda is also likely to induce capital costs upon firms in industries where IPRs infringed more frequently. Most likely victims are producers of counterfeit goods of clothing, perfumes and cosmetics, bags, shoes and watches, and unlicensed software users, which reportedly constitute $60 \%$ of domestic sectors causing US\$504 million value of commercial loss to American right-holders (EC, 2013, p. 34; USTR, 2016b, p. 56). The government

\footnotetext{
${ }^{17}$ The study does not mention Turkey but lists Mexico which has an identical per capita income as per the International Monetary Fund data.
} 
will need to contrast these costs with potential benefits of enhanced and better-enforced standards, which may induce innovation and investment for manufacturing higher technology products.

Against such upsides and downsides of a "TTIP plus Turkey" scenario, Turkey is in an advantageous position in a baseline scenario in comparison with other third parties. Enhanced regulatory convergence in the transatlantic marketplace will allow the excluded countries to benefit from additional market access without joining a TTIP. Francois et al. (2013) expect the direct spillovers to diminish trade costs for third countries by $20 \%$. An additional $10 \%$ advantage is also anticipated as indirect spillovers to the third parties like Switzerland and Turkey which have been streamlining their standards with TTIP partners' (Francois et al., 2013, pp. 28-29). These third countries are likely to benefit more from transatlantic regulatory convergence to the extent the USA and EU remove existing NTBs in a non-discriminatory manner (Cottier et al., 2014, pp. 4-5). In this respect, the methodology for transatlantic regulatory convergence will have a critical importance in determining the implications of TTIP for Turkey especially in deciding upon the most feasible mechanism to re-engage with the emerging transatlantic commercial framework.

\section{\begin{tabular}{l|l}
7 & CONCLUSION
\end{tabular}}

If successfully concluded and ratified by the United States and EU, TTIP will have significant economic and policy implications for members and other countries contingent upon its ability to dismantle outstanding trade and investment barriers and to ensure higher regulatory convergence in the Atlantic region and beyond. While different estimations have so far been produced for the impact of the agreement upon the Turkish economy, they do not account for significant potential implications of the regulatory agenda underpinning TTIP and alternative/parallel mechanisms for Turkey to better engage with transatlantic economies.

Even though NTBs lie at the heart of market access, tariffs remain a significant barrier to US and EU exports destined to Turkey, especially in the farming sector. Materialisation of the TTIP project will augment US industrial exports to Turkey because of the Customs Union, whereas a "TTIP plus Turkey" that also removes Turkish tariffs on agricultural products will boost imports in this sector both from Europe and the United States. Tariff-only scenarios suggest only modest benefits to Turkish exporters in various product groups. Comprehensive "TTIP plus Turkey" scenarios are where greater benefits lie for Turkish as well as transatlantic exporters depending on comparative advantage in product groups especially in manufacturing. However, the Turkish farming sector will potentially be affected negatively from deeper trade liberalisation that would entail the removal of NTBs owing to low productivity in the sector and poorer SPS standards. Unless the government undertakes costly investments to improve production standards, Turkish agri-food exporters will enjoy lower benefits than expected from market-opening scenarios, which would also lead to unemployment in rural areas.

A comprehensive baseline scenario may also cause an investment diversion from Turkey that might be partially offset by Turkey's joining the transatlantic FTA or a Turkish engagement in a flanking agreement with the United States (e.g., a BIT or FTA covering investment). Nevertheless, a "TTIP plus Turkey" scenario (or signing of a flanking agreement with the USA) will require Turkey to commit to an ISDS tribunal and higher standards for protection of investors in addition to eliminating outstanding investment barriers in protected Turkish service industries. There is no sustainable evidence to suggest that Turkey could ensure substantive export gains in services in an association 
scenario, whereas imports will likely grow in professional and some other service sectors. Finally, the liberalisation of government procurement markets under a "TTIP plus Turkey" option is likely to lead to internal challenges as well as opportunities for Turkish producers in Western markets. Nevertheless, the market access impacts of TTIP per se for services and government procurement might be negligible since Turkey will potentially undersign other agreements with Atlantic economies before the materialisation of a "TTIP plus Turkey" scenario.

The regulatory content of a transatlantic agreement will further calibrate expected gains and costs in different scenarios. Adoption of stronger disciplines in competition policy, subsidies, SOEs and trade facilitation as well as government procurement is likely to have "procompetitive" effects on the Turkish economy despite limited implementation costs. However, these disciplines as well as others are likely to shrink the government's policy space to intervene in markets for developmental objectives and cost-effective healthcare policies. Labour and environmental standards, IPRs, as well as SPSrelated rules, seem to be major "norm-setting" areas with potentially higher economic costs than benefits in case of Turkey's association with TTIP. Potential compliance costs are likely to be smaller in a baseline scenario since Turkish firms will benefit from positive spillovers in the form of better access to transatlantic markets without Turkey's association with TTIP, especially if the USA and EU remove remaining NTBs in a non-discriminatory manner. Furthermore, Turkey may still diversify its ties with the USA by adopting more sophisticated export promotion strategies that would address the issues of scale, quality, consumer taste, logistics and product mismatch.

\section{ACKNOWLEDGEMENTS}

The author is grateful to the reviewers for their careful and meticulous reading of the paper, and their invaluable inputs. I am also thankful to Prof. Kemal Kirisci, Dr. Guzin Bayar, Dr. Talat Kaya, Demet Isil Karakurt and Necmettin Kaymaz for offering their support and helpful comments on the earlier drafts.

\section{REFERENCES}

Adalet ve Kalkınma Partisi (AKP) (2012). AK Parti 2023 Siyasi Vizyonu: Siyaset, Toplum, Dunya. Retrieved from https://www.akparti.org.tr/site/akparti/2023-siyasi-vizyon (accessed 1 September 2016).

Akman, M. S. (2012). Turkey in the world trading system and the WTO: Activism under global challenges and the EU process. Afro Eurasian Studies, 1(1), 134-172.

Akman, M. S. (2013). AB - ABD Transatlantik Ticaret ve Yatırım Ortaklıgı (TTIP) ve Turkiye. Ankara: Turkiye Ekonomi Politikaları Arastırma Vakfı.

Anuradha, R. V. (2011). Environment. In J. P. Chauffour \& J. C. Maur (Eds.), Preferential trade agreement policies for development: A handbook (pp. 407-425). Washington, DC: World Bank Publications.

Aran, B. (2015). Turkiye: Transatlantik Ticaret ve Yatirim Ortakliginin Sonuclari, Degerlendirme Notu. Ankara: Turkiye Ekonomi Politikaları Arastırma Vakfı.

Atalay, I. (2011). Turkiye'nin Dis Ticaretinde Serbest Ticaret Anlasmalari Hakkinda Bilgi ve Degerlendirme Notu. Ankara: TOBB.

Baldwin, R. (2009). Big-think regionalism: A critical survey. In A. Estevadeordal, K. Suominen \& R. Teh (Eds.), Regional rules in the global trading system (pp. 17-95). Cambridge: Cambridge University Press.

Baldwin, R. (2011). Economics. In J. P. Chauffour \& J. C. Maur (Eds.), Preferential trade agreement policies for development: A handbook (pp. 69-93). Washington, DC: World Bank Publications.

Boston Consulting Group (2011). Achieving Turkey's fair share within US FDI: Final Steering Committee Presentation, 6 May, Istanbul.

Cetingulec, M. (2014). Will US-EU trade deal dissolve EU-Turkey customs union? Almonitor, November 18. 
Retrieved from http://www.al-monitor.com/pulse/originals/2014/11/turkey-us-eu-trade-deal-hit-turkeyscustomsunion.html\#ixzz3b8u0G6gU (accessed 15 September 2016).

Chauffour, J. P., \& Maur, J. C. (2011a). Overview. In J. P. Chauffour \& J. C. Maur (Eds.), Preferential Trade Agreement Policies for Development: A Handbook (pp. 1-16). Washington, DC: World Bank Publications.

Chauffour, J. P., \& Maur, J. C. (2011b). Beyond market access. In J. P. Chauffour \& J. C. Maur (Eds.), Preferential trade agreement policies for development: A handbook (pp. 17-36). Washington, DC: World Bank Publications.

Ciuriak, D. (2014), Mega regionals and the developing countries, Commentary for Trade Workshop, 24 June. Washington, DC: Center for Global Development and International Institute for Sustainable Development.

Ciuriak, D., \& Singh, H. V. (2015). Mega regional trade agreements: How excluded countries can meet the challenge. Report for International Institute for Sustainable Development, Knowledge Partnership Programme, and IPE Global, 18 August. Available from http://www.ipekpp.com/admin/upload_files/Report_3_54_Mega_ 6625696643.pdf (accessed 16 June 2016).

Cottier, T., Egger, P., Francois, J., Manchin, M., Shingal, A., \& Gasser, C. S. (2014). Potential impacts of a EU-US free trade agreement on the Swiss economy and external economic relations. Bern: World Trade Institute, University of Bern.

Donnelly, S. (2013). Putting the I in TTIP: The necessity of a strong investment chapter. Retrieved from http:// www.investmentpolicycentral.com/content/putting-i-ttip-necessity-strong-investment-chapter $\quad$ (accessed 15 September 2016).

Ecorys (2009). Non-tariff measures in the EU-US trade and investment: An economic analysis, Ref. OJ 2007/S 180219493, Final Report. Rotterdam: ECORYS Nederland BV.

Elliott, K. A. (2011). Labor rights. In J. P. Chauffour \& J. C. Maur (Eds.), Preferential trade agreement policies for development: A handbook (pp. 427-441). Washington, DC: World Bank Publications.

Eruygur, H. O. (2012). Impacts of agricultural trade liberalization between EU and mediterranean partners countries. Report for SUSTAINMED Project for EU 7th Framework Programme. Retrieved from http://www.ozane ruygur.com/PAPER_R4.pdf (accessed 5 September 2016).

European Commission (EC) (2013). Report on EU customs enforcement of intellectual property rights: Results at the EU border 2012. Brussels: EC.

European Commission (EC) (2015a). Turkey 2015 Report. Commission Staff Working Document Accompanying the document Communication From the Commission to the European Parliament, the Council, The European Economic and Social Committee and the Committee of the Regions, SWD(2015) 216 final. Brussels: EC.

European Commission (EC) (2015b). Online public consultation on investment protection and investor-to-state dispute settlement (ISDS) in the Transatlantic Trade and Investment Partnership Agreement (TTIP) (Commission Staff Working Document Report, SWD(2015) 3 final). Brussels: EC.

Felbermayr, G., Heid, B., \& Lehwald, S. (2013). Transatlantic Trade and Investment Partnership (TTIP) Who benefits from a free trade deal?: Part 1: Macroeconomic Effects. G€utersloh: Bertelsmann Stiftung, Global Economic Dynamics.

Felbermayr, G., Larch, M., Flach, L., Yalcin, E., \& Benz, S. (2013). Dimensions and effects of a transatlantic free trade agreement between the EU and US, February. Munich: IFO Institute.

Francois, J., Manchin, M., Norberg, H., Pindyuk, O., \& Tomberger, P. (2013), Reducing trans-atlantic barriers to trade and investment: An economic assessment. London: Centre for Economic Policy Research.

High Level Working Group on Jobs and Growth (HLWG) (2013). Final Report, 11 February. Retrieved from http://trade.ec.europa.eu/doclib/docs/2013/february/tradoc_150519.pdf (accessed 16 June 2016).

Hoekman, B. M. (2011). North-South preferential trade agreements. In J. P. Chauffour \& J. C. Maur (Eds.), Preferential trade agreement policies for development: A handbook (pp. 95-110). Washington, DC: World Bank

Publications.

Hoekman, B. M., Mattoo, A., \& Sapir, A. (2007). The political economy of services trade liberalization: A case for international regulatory cooperation? Oxford Review of Economic Policy, 23(3), 367-391.

Hoekman, B. M., \& Mavroidis, P. C. (2015). Regulatory spillovers and the trading system: from coherence to cooperation (Overview Paper, E15 Task Force on Regulatory Systems Coherence). Retrieved from http://e15initia tive.org/wp-content/uploads/2015/04/E15-Regulatory-OP-Hoekman-and-Mavroidis-FINAL.pdf (accessed 16 June 2016) 
Horn, H., Mavroidis, P. C., \& Sapir, A. (2010). Beyond the WTO? An anatomy of EU and US preferential trade agreements. The World Economy, 33(11), 1565-1588.

Hufbauer, G. C., Jensen, J. B., \& Stephenson, S. (2012). Assisted by J. Muir, and M. Vieiro, Framework for the International Services Agreement. Policy Brief, No PB 12-10. Washington, DC: Peterson Institute for International Economics.

Kaleagasi, B., \& Ornarli, B. (2013). Why Turkey belongs to transatlantic economy? Congress Blog, March 12, Retrieved from https://thehill.com/blogs/congress-blog/foreign-policy/287675-why-turkey-belongs-totransatlanticeconomy (accessed 1 August 2016).

Kim, S. Y. (2015). Deep integration and regional trade agreements. In L. L. Martin (Ed.), The Oxford handbook of the political economy of international trade (pp. 360-379). Oxford: Oxford University Press.

Kirisci, K. (2013). Turkey and the transatlantic trade and investment partnership (Turkey Project Policy Paper 2). Washington, DC: Brookings Institution. Retrieved from https://www.brookings.edu/wp-content/uploads/2016/06/ Turkey-and-the-Transatlantic-Trade-and-Investment-Partnership.pdf (accessed 16 June 2016).

Kirisci, K. (2015). TTIP's enlargement and the case of Turkey (Turkey Papers), January. Washington, DC: Istanbul Policy Center, Wilson Center. Retrieved from https://www.wilsoncenter.org/sites/default/files/FINAL_IPC-WWIC STurkeyPaper_TTIP.pdf (accessed 16 June 2016).

Lester, S. (2014). One year into the TTIP negotiations: Getting to yes. Free Trade Bulletin, Herbert A. Stiefel Center for Trade Policy Studies, No. 59. Retrieved from https://www.wto.org/english/res_e/reser_e/ersd201311_e.pdf (accessed 16 June 2016).

Marchetti, J. A., \& Roy, M. (2013). The TiSA initiative: An overview of market access issues (Staff Working Paper, ERSD-2013-11). Geneva: World Trade Organization Economic Research and Statistics Division. Retrieved from https://www.ceps.eu/system/files/SR106\%20TTIP\%20Services\%20Messerlin\%20.pdf (accessed 16 June 2016)

Mavus, M., Oduncu, A., \& G€unes, D. (2013). AB-ABD Serbest Ticaret Anlasması ve Turkiye Uzerine Etkileri.€

Turkiye Cumhuriyeti Merkez Bankası Ekonomi Notları, 2013-30, 26 Kasım.

McKinsey and Company (2009). A diagnostic overview of Turkish exports to the United States. The Turkey-US Business Council Board Presentation, Ankara.

Messerlin, P. (2008). The EC neighbourhood policy: An economic review. The Journal of International Trade and Diplomacy, 2(2), 27-54.

Messerlin, P. (2014). The Transatlantic Trade and Investment Partnership: Ambiguities, opportunities, challenges.

Kokusai Mondai (International Affairs), No.632.

Messerlin, P. (2015). The Transatlantic Trade and Investment Partnership: The Services Dimension Paper' No. 6 in the CEPS-CTR project 'TTIP in the Balance' and CEPS Special Report. Retrieved from https://www.ceps.eu/ system/files/SR106\%20TTIP\%20Services\%20Messerlin\%20.pdf (accessed 16 June 2016).

Ministry of Economy (MoE) (2015). Pazara Giris Engelleri 2015 Raporu. Ankara: Anlasmalar Genel M€ud€url€ug€u.

Retrieved from http://www.ekonomi.gov.tr/portal/content/conn/UCM/path/Contribution\%20Folders/web/\%C4\% B0hracat/Pazara\%20Giri\%C5\%9F/ekler/Pazara\%20Giri\%C5\%9F\%20Engelleri\%202015\%20Raporu.pdf?lve (accessed 21 September 2016).

Narayanan, B. G., Ciuriak, D., \& Singh, H. V. (2015). Quantifying TTP and TTIP Spillovers on India, Report for International Institute for Sustainable Development, Knowledge Partnership Programme, and IPE Global, 17 August. Retrieved from IPE website: http://www.ipekpp.com/admin/upload_files/Report_3_54_Quantifying _ 6385658760.pdf (accessed 16 June 2016).

Onis, Z., \& Kutlay, M. (2013). Rising powers in a changing global order: The political economy of Turkey in the age of BRICs. Third World Quarterly, 34(8), 1409-1426.

Plummer, M. G., Cheong, D., \& Hamanaka, S. (2010). Methodology for impact assessment of free trade agreements. Manila: Asian Development Bank.

Porto, G. G., \& Hoekman, B. M. (Eds) (2010). Trade adjustment costs in developing countries: Impacts, determinants and policy responses. Washington, DC: International Bank for Reconstruction and Development/The World Bank.

Schott, J. J., \& Cimino, C. (2013). Crafting a transatlantic trade and investment partnership: What can be done.

Policy Brief, (March 2013): 13-18. Washington, DC: Peterson Institute for International Economics. 
Sidar Global Advisors (SGA) (2012). US-Turkish Economic Relations in a New Era: Analysis and Recommendations for a Stronger Strategic Partnership. Report for US Chamber of Commerce and Turkish Industry and Business Association. Retrieved from http://www.uschamber.com/sites/default/files/reports/20120312-USCC-Report. pdf (accessed 1 September 2016).

Stoler, A. L. (2011). TBT and SPS measures in practice. In J. P. Chauffour \& J. C. Maur (Eds.), Preferential trade agreement policies for development: A handbook (pp. 217-233). Washington, DC: World Bank Publications.

Togan, S. (2015). The EU-Turkey customs union: A model for future Euro-Med integration. In R. Ayadi, M. Dabrowski \& L. De Wulf (Eds.), Economic and social development of the Southern and Eastern Mediterranean Countries (pp. 37-48). London: Springer International Publishing.

Turkiye Odalar ve Borsalar Birligi (TOBB) (2013). DTO Kamu Al€ ımları Anlasması, Turkiye Odalar ve Borsalar Birligi'nin Ekonomi Bakanligi Anlasmalar Genel Mudurlugu'ne yazisi, Communication to the Ministry of Economy, 0402/4569, 28 February.

United States Commercial Service (USCS) (2014). Doing business in Turkey: 2014 Country commercial guide for US Companies, US Commercial Service. Washington, DC: US Department of State.

United States Trade Representation (USTR) (2014a). 2014 report on sanitary and phytosanitary measures. Washington, DC: Office of the United States Trade Representation.

United States Trade Representation (USTR) (2014b). 2014 Report on technical barriers to trade. Washington, DC: Office of the United States Trade Representation.

United States Trade Representation (USTR) (2016a). 2016 national trade estimate report on foreign trade barriers. Washington, DC: Office of the United States Trade Representation.

United States Trade Representation (USTR) (2016b). 2016 special 301 report. Washington, DC: Office of the United States Trade Representation.

van Leeuwen, M., Salamon, P., Fellmann, A., Koc, A., B€ol€uk, G., Tabeau, A., ... Hanrahan, K. (2011). Potential impacts on agricultural commodity markets of an EU enlargement to Turkey: Extension of the AGMEMOD model towards Turkey and accession scenario. JRC Scientific and Technical Reports, EUR 24772 EN - 2011. Retrieved from ftp://s-jrcsvqpx102p.jrc.es/pub/EURdoc/JRC60663.pdf (accessed 16 June 2016).

World Bank (2010). Needs assessment for modernization of food establishments. Report of II gap analysis of agriFood enterprises, Turkey food safety programmatic technical assistance. Washington, DC: World Bank.

World Bank (2014a). Evaluation of the EU-TURKEY Customs Union, March 28, Report No. 85830-TR. Washington DC: World Bank.

World Bank (2014b). Trading up to high income, 5 May, Report No. 82307-TR. Washington, DC: World Bank.

World Trade Organization (WTO) (2012). World trade report 2011. The WTO and preferential trade agreements:

From co-Existence to coherence. Geneva: World Trade Organization.

World Trade Organization (WTO) (2015). International trade statistics 2015. Geneva: World Trade Organization.

World Trade Organization (WTO) (2016a). Trade policy review, report by the Secretariat: Turkey, WT/TPR/S/331.

Geneva: World Trade Organization.

World Trade Organization (WTO) (2016b). Trade policy review, Turkey: Minutes of the meeting, Addendum, WT/ TPR/M/331/Add.1 Geneva: World Trade Organization.

World Trade Organization, International Trade Center, \& United Nations Conference on Trade and Development (2015). World tariff profiles 2015. Retrieved from https://www.wto.org/english/res_e/booksp_e/tariff_profile s15_e.pdf (accessed 15 September 2016).

Yesilyurt, S., \& Paul, A. (2013). Between a rock and a hard place: What is Turkey's place in the transatlantic market? Commentary, 9 July. Brussels: European Policy Centre.

Yilmaz, G. (2011). Resurgence of selective industrial policy: What Turkey needs (Discussion Paper, No. 2011/3). Retrieved from Turkish Economic Association website: http://tek.org.tr/dosyalar/YILMAZ-Industrial\%20Policy0311.pdf (accessed 14 July 2017). 